Article

\title{
Battery Life Enhancement in a Hybrid Electrical Energy Storage System Using a Multi-Source Inverter
}

\author{
Yogesh Mahadik * and K. Vadirajacharya \\ Department of Electrical Engineering, Dr. Babasaheb Ambedkar Technological University, \\ Lonere 402104, Maharashtra, India; kvadirajacharya@dbatu.ac.in \\ * Correspondence: yogi_maha@yahoo.co.in
}

Received: 13 February 2019; Accepted: 1 April 2019; Published: 12 April 2019

Featured Application: This research work can used in designing energy management systems (EMS) for pure electric vehicles, which will enhance driving range, lower the energy storage system cost, and result in higher efficiency and improved lifetime of storage batteries.

\begin{abstract}
This paper introduces a new topology using a multi-source inverter with the intention of reducing the battery current and weight, while enhancing the battery life and increasing the driving range for plug-in electric vehicles, with the combination of a battery and an ultracapacitor (UC) as storage devices. The proposed topology interconnects the UC and battery directly to the three-phase load with a single-stage conversion using an inverter. The battery life is considerably reduced due to excess (peak) current drawn by the load, and these peak load current requirements are met by connecting the ultracapacitor to the battery, controlled through an inverter. Here, the battery is used to cater to the needs of constant profile energy demands, and the UC is used to meet the dynamic peak load profile. This system is highly efficient and cost-effective when compared to a contemporary system with a single power source. Through a comparative analysis, the cost-effectiveness of the proposed energy management system (EMS) is explained in this paper. Energy and power exchange are implemented with an open-loop control strategy using the PSIM simulation environment, and the system is developed with a hardware prototype using different modes of inverter control, which reduces the average battery current to $27 \%$ compared to the conventional case. The driving range of electric vehicles is extended using active power exchange between load and the sources. The dynamics of the ultracapacitor gives a quick response, with battery current shared by the ultracapacitor. As a result, the battery current is reduced, thereby enhancing the driving cycle. With the prototype, the results of the proposed topology are validated.
\end{abstract}

Keywords: energy management system (EMS); power management; inverter; ultracapacitor (UC); battery; optimum sizing of EMS

\section{Introduction}

As everyone is aware, fuel sources are dwindling day by day and demand is increasing at a rapid pace, resulting in an exponential rise in prices. In today's scenario, due to the increase in cost and pollution, there is an urgent requirement for attractive and reliable solutions to replace conventional vehicles, which can cater to the needs of society as a whole. Keeping this in mind, the manufacturing of electric vehicles is taking rapid strides.

Basically, there are three types of electric vehicles: battery electric vehicles, hybrid electric vehicles, and plug-in hybrid electric vehicles. Out of these, battery electric vehicles are totally powered by electrical energy. On the other hand, hybrid electric vehicles operate on multiple sources, such as an internal combustion engine (ICE), fuel cell, or renewable energy source [1-5]. 
Unlike hybrid electric vehicles, plug-in electric vehicles can be recharged externally using either a domestic supply or charging stations. Also, the main advantage of plug-in hybrid electric vehicles is that the smart grid concept can be applied, which means that the battery in the electric vehicle works as a sink or source with an electric grid [6,7].

Several distinguished authors [8-12] shed light on the research design by considering different objectives with respect to electric vehicles, as outlined below.

Remaining useful life (RUL) is affected due to the peak loading conditions of the battery storage system, which also results in a severe degradation of system level performance and affects safety concerns. Li et al. [8] suggested a hybrid RUL prediction model using the long short-term memory (LSTM) and Elman neural networks, which could simultaneously capture the battery capacity degradation characteristics with increased cycle number in the long term and represent the capacity recovery at certain cycles in the short term. Zhang et al. [9] focused on a comprehensive analysis of the thermal safety issues of lithium ion batteries, in terms of thermal behavior, thermal runaway modeling, and safety management strategies for battery packs, considering the heat production mechanisms and thermal characteristics of batteries. In addition to the different engineering approaches to material refinement, certain additives from thermal, electrical, and mechanical designs were required for thermal runaway prevention. Li et al. [10] emphasized the analysis of accurate battery state-of-health $(\mathrm{SOH})$ monitoring, which is crucial to guarantee the safe and reliable operation of electric vehicles. In this paper, an incremental capacity analysis (ICA) for battery $\mathrm{SOH}$ estimation was elaborated. This method used gray relational analysis in combination with the entropy weight method. The health indices were then extracted from the partial incremental capacity curves for gray relational analysis, and the entropy weight method was used to evaluate the significance of each health index. The battery $\mathrm{SOH}$ was assessed by calculating the gray relational degree between the reference and comparative sequences. Based on the experimental analysis of the two batteries with the same specifications, the results were validated using a combination of the incremental capacity analysis method (ICA) with gray relational analysis (GRA). The GRA method was used to quantitatively calculate the difference between the reference and comparative sequences.

On the other hand, in the study by Wang et al. [11], the $\mathrm{SOH}$ model was further established on the basis of Gaussian process regression (GPR), in which the optimal hyper parameters were calculated through the conjugate gradient method and the multi-island genetic algorithm (MIGA). The effects of different kernel functions were also analyzed. The multi-island genetic algorithm was validated to find a SOH estimation scheme and was verified through the accelerated battery life test. Zhang et al. [12] stressed the optimization of a hybrid energy storage system (HESS) sizing the considering coordinated operation of a battery and ultracapacitor using $\mathrm{SOH}$, weight, and cost as objectives.

From the above references, it is evident that hybridization enhances remaining useful life, prevents thermal runaway, maintains state of health, and optimizes weight, leading to a reduction in EMS size. The cumulative effect of all these parameters is the enhancement of overall battery life and the driving cycle of electric vehicles, which eventually makes the system cost-effective.

This paper gives deep insight into the effects of different modes of hybridization on the above objectives with the help of a simulation and hardware analysis.

In electrical vehicles, the battery is the main source of energy. Batteries used in electrical vehicles have certain drawbacks, such as a lower life cycle, a high charging time, a lower rate of charge-discharge, and lesser power density. The high discharge rate of batteries affects the energy-delivering capacity. The battery temperature increases due to the internal resistance of the battery. In energy storage systems, the battery is one of the most important elements. Thus, the safe operation of the battery is challenged at peak load. In battery-based energy storage systems, the balancing of the cell is a major concern, whereby frequent charging and discharging adversely affect the battery life [4].

The above problems were approached using the combined operation of an ultracapacitor (UC) and battery, where different methods were used to enhance the battery life via the combined battery-UC 
topology. The UC ensured proper utilization of energy and also controlled thermal management and peak power demand, thus leading to an increase in the efficiency of the vehicle as a whole [13-15].

The Ragone plot gives an idea about the comparative study of the power and energy density performance of various energy devices. From this plot, it is evident that the batteries have a relatively high energy density but lower power density. On the contrary, the UC has a much lower energy density and a sufficiently higher power density. In addition, the life cycle of the UC is much higher than that of batteries. Furthermore, UCs have a better low-temperature performance than batteries. Figure 1 shows the Ragone plot. Hence, the combination of an Li-ion battery and a UC was used to get better results. From the Ragone chart, we can conclude that the power density of UC is high $(6800 \mathrm{~W} / \mathrm{kg})$; therefore, the UC fulfills the peak load demand. On the other hand, the energy density of a battery is high (up to 100 to $265 \mathrm{Wh} / \mathrm{kg}$ ); therefore, the combination offers better performance as compared to the use of either alone $[4-7,13]$.

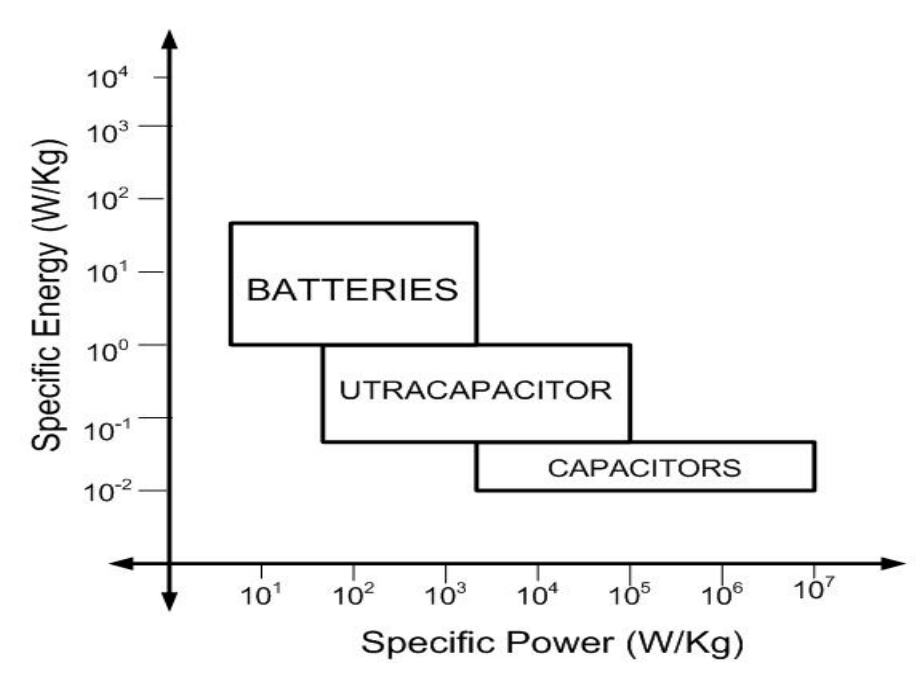

Figure 1. Ragone plot.

Table 1 represents a comparison of various energy storage elements. According to the table, the battery is more suited to provide High Specific Energy (HSE), whereas the ultracapacitor is more suited to provide High Specific Power (HSP). Hence a combination of ultracapacitor and battery gives excellent performance.

Table 1. Comparison of energy storage elements.

\begin{tabular}{cccccc}
\hline Sr. No. & Storage Element & Specific Energy Density (Wh/Kg) & Energy Density (Wh/Ltr) & Power Density (W/kg) & Cycle/Life \\
\hline 1 & Lead Acid Battery & 40 & 80 & 100 & 1000 \\
2 & Ni-MH & 80 & 200 & 100 to 250 & 2000 \\
3 & High-energy Li-Ion & 77 & 250 & 750 to 1500 & 2000 \\
4 & Ultra-capacitor & 4.5 & 6.4 & 2000 & 500,000 \\
\hline
\end{tabular}

\subsection{Comparative Analysis of Energy management system (Cost, Weight)}

As a case study, a comparative analysis that clarifies the effectiveness of the hybridization of sources is carried out. An energy management system is designed based on the peak power requirements of an electric vehicle. A conventional energy management system consists of batteries that deliver both peak power and energy to the vehicle. The Ragone chart gives an idea of the power and energy densities of various energy and power sources. Some researchers [14] carried out a comparative analysis by using a battery alone, an ultracapacitor alone and combining the two sources, i.e., the battery and ultracapacitor. On the basis of different driving cycles, peak power requirements are considered $20 \%$ in the entire driving cycle. Consider a vehicle as having $150 \mathrm{~kW}$ as the maximum power requirement, from which $30 \mathrm{~kW}$ is the peak power requirement and $120 \mathrm{~kW}$ is the average power requirement. 
Conventional battery-based energy management systems are designed for $150 \mathrm{~kW}$, so the system becomes bulky (100 kg). As per the datasheet and the Ragone chart, an ultracapacitor provides peak power demand $6800 \mathrm{~W} / \mathrm{kg}$, but the energy rating is $4.1 \mathrm{Wh} / \mathrm{kg}$, so this system $(22.05 \mathrm{~kg})$ cannot fulfill the continuous energy demands of a vehicle. As a solution, batteries can be used with an ultracapacitor (hybrid EMS) having a high power-delivering capability $(6800 \mathrm{~W} / \mathrm{kg})$ and energy delivering capability of $4.1 \mathrm{Wh} / \mathrm{kg}$. This effectively minimizes the average $\mathrm{W} / \mathrm{kg}$ of the system by reducing cost, weight with enhancing life (due to reduction in peak currents), and performance of vehicle due to fast dynamics of ultracapacitor [14]. Using the market costs of batteries and ultra-capacitors, a comparative analysis is carried out as follows in Tables 2 and 3.

Table 2. Specifications of the battery and ultracapacitor.

\begin{tabular}{ccc}
\hline Specifications & Battery (EME LIR18650) & Ultracapacitor (Maxwell BCAP0650) \\
\hline Rated Capacity & - & $650 \mathrm{~F}$ \\
Rated Voltage & $3.7 \mathrm{Volt}$ & $2.70 \mathrm{~V}$ \\
Mass Typical & $46 \mathrm{~g}$ & $160 \mathrm{~g}$ \\
Specific Power & $1500 \mathrm{~W} / \mathrm{kg}$ & $6800 \mathrm{~W} / \mathrm{kg}$ \\
Specific Energy & $265 \mathrm{Wh} / \mathrm{kg}$ & $4.1 \mathrm{Wh} / \mathrm{kg}$ \\
Life & $5-10$ years & 10 to 15 years \\
Cost & $\$ 224 / \mathrm{kW}$ & $\$ 500 / \mathrm{kW}$ \\
\hline
\end{tabular}

Table 3. Comparative analysis for energy management system.

\begin{tabular}{|c|c|c|c|c|c|c|}
\hline & \multicolumn{2}{|c|}{ EMS Using Battery } & \multicolumn{2}{|c|}{ EMS Using Ultracapacitor } & \multicolumn{2}{|c|}{$\begin{array}{l}\text { EMS using Battery and Ultracapacitor (Hybrid } \\
\text { EMS) }\end{array}$} \\
\hline & Weight (Kg) & Cost (\$) & Weight $(\mathrm{Kg})$ & Cost (\$) & $\mathrm{Wt}(\mathrm{Kg})$ & Cost (\$) \\
\hline UC pack & & - & $150 \times 1000 / 6800$ & $150 \times 500$ & $30 \times 1000 / 6800$ & $30 \times 500$ \\
\hline Battery Pack & $150 \times 1000 / 1500$ & $150 \times 224$ & - & - & $120 \times 1000 / 1500$ & $120 \times 224$ \\
\hline Total & 100 & 33,600 & 22.05 & 75,000 & $\begin{array}{c}\mathrm{UC}=4.41 \mathrm{~kg}+\text { Battery }= \\
80 \mathrm{~kg}=84.41 \mathrm{~kg}\end{array}$ & $1500+26880=\mathbf{2 8 , 3 8 0}$ \\
\hline
\end{tabular}

Hybrid EMS weight and cost decreased by $15.59 \%$ and $15.53 \%$, respectively. Penetration of the ultra-capacitor leads to a savings in terms of maintenance and EMS replacement costs.

\subsection{Overview of developed strategies in HESS (Hybrid Energy Storage System)}

In conventional methods the rechargeable battery or UC combination is used. Batteries were charged through a plug-in charging system while the vehicle was idle; there is a requirement for large DC/DC converters. However, these converters are expensive and make the system bulky. Also, the use of these converters adversely affects the efficiency of the electric vehicle $[15,16]$.

Figure 2 shows a DC/DC converter, which aims to use a basic combined rechargeable battery and UC to obtain constant voltage and power output and utilizes UC power to meet peak current demand.

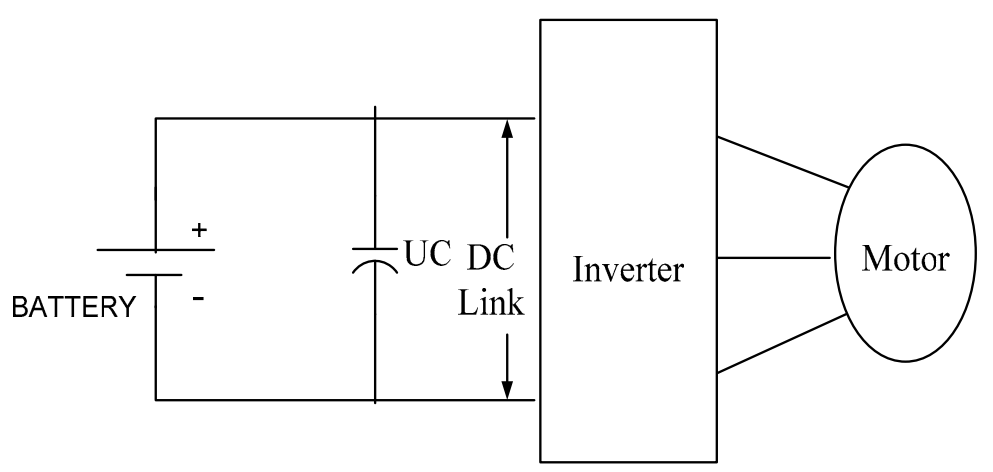

Figure 2. Passive parallel design. 


\subsubsection{Passive Parallel Design}

In this design, the combination of a battery and ultracapacitor is directly connected to the load without using a power electronic converter; hence, this design is cheap and compact as compared to other designs because of the absence of a DC/DC converter [10,15]. As the charging and discharging dynamics of UC is fast compared to a battery, UC gets discharges in load before battery and it frequently takes a current to maintain the terminal voltage; thus, the battery suffered from frequent charges.

\subsubsection{UC/Battery Design}

This design is more complex than a passive parallel one. In the Figure 3 below, the battery is connected directly to a DC link and the UC is connected to the DC link via a DC/DC converter.

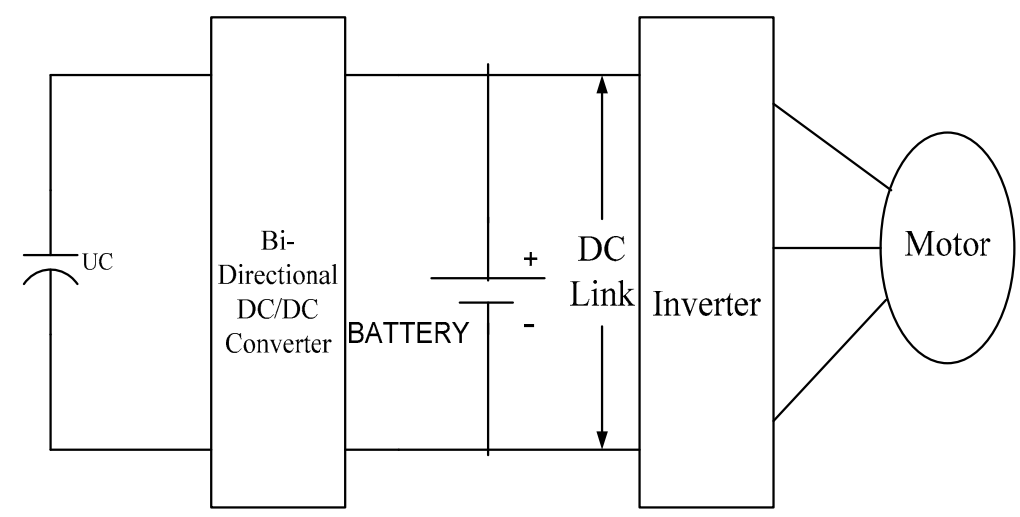

Figure 3. UC/battery design.

This design is advantageous in the sense that there is no variation in the DC link voltage [11]; the major drawback is that it requires a large converter to handle the power of UC. Hence, it adversely affects the cost and size of the ESS (Energy Storage System). Partial active control is possible due to a bidirectional DC/DC converter.

\subsubsection{Battery/UC Design}

This design is configured by simply switchingthe positions of the UC and battery in the above design. Here (Figure 4) the battery is connected to the DC link via a DC/DC bidirectional converter, whereas the UC is connected directly to the DC link. Here, the main objective of using the converter is to supply a specific constant power from the battery to the load by controlling the source current. On the other hand, the converter is much smaller than that used in UC/battery design and the main advantage of this design is the wide power range of UC [11].

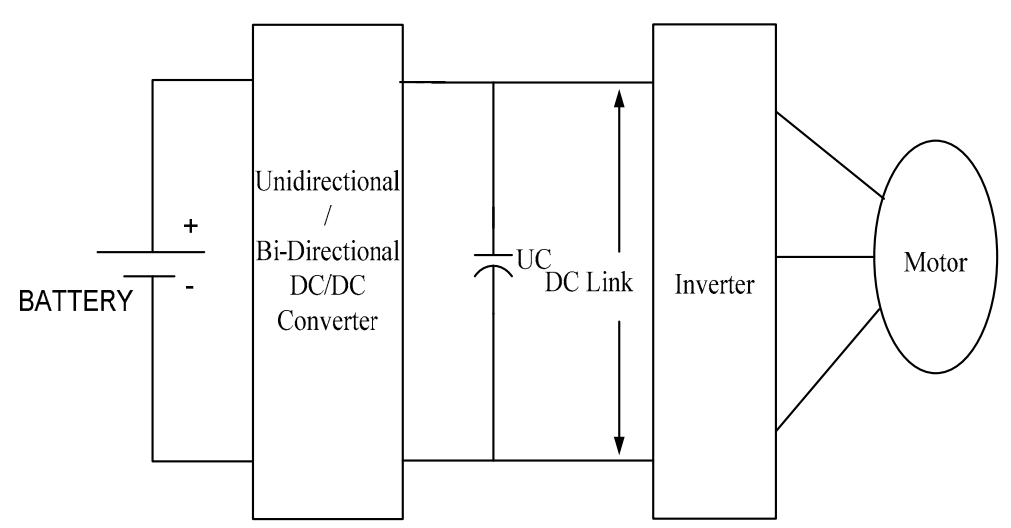

Figure 4. Battery/UC design. 
In order to understand the operation using Battery/UC design, there are four operating modes as follows:

\section{Mode-1: Slow Constant Speed}

In this mode, the converter power is always greater than the demand power, hence only the battery provides power to the three-phase motor through a DC/DC converter, i.e., boost operation, as shown in Figure 5.

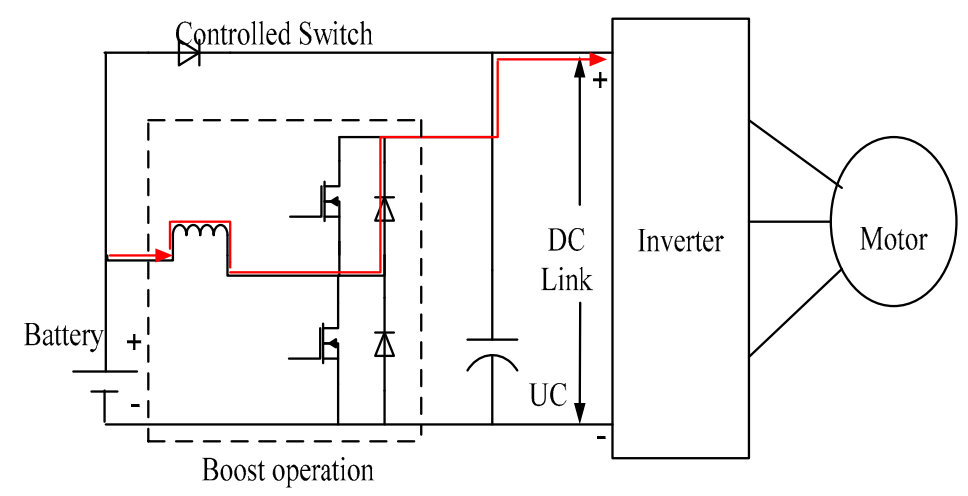

Figure 5. Slow constant-speed operation.

\section{Mode-2: Fast Constant Speed}

In this mode (Figure 6), the demand power is greater than the converter power; therefore, the control switch is forward biased and the battery supplies power directly to the motor. In this mode, a DC/DC converter is not used. In constant-speed mode, the UC voltage is higher than the battery voltage and hence in this mode UC does not absorb or provide power to the three-phase motor [16].

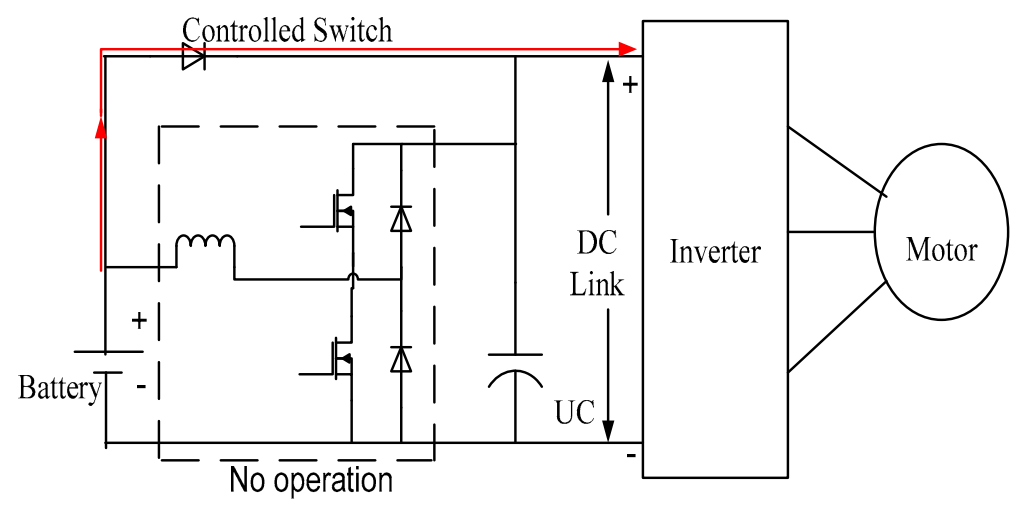

Figure 6. Fast constant-speed operation.

Mode-3: Acceleration

At the inception of acceleration (Figure 7), the UC voltage is greater than the battery voltage and the demand power is greater than the converter power. Therefore, both UC and battery via the converter. As the rate of acceleration remains constant, the UC voltage drops to the same level as the battery voltage; consequently, the battery and UC directly combine through a control switch and provide power to the three-phase motor $[15,16]$. 


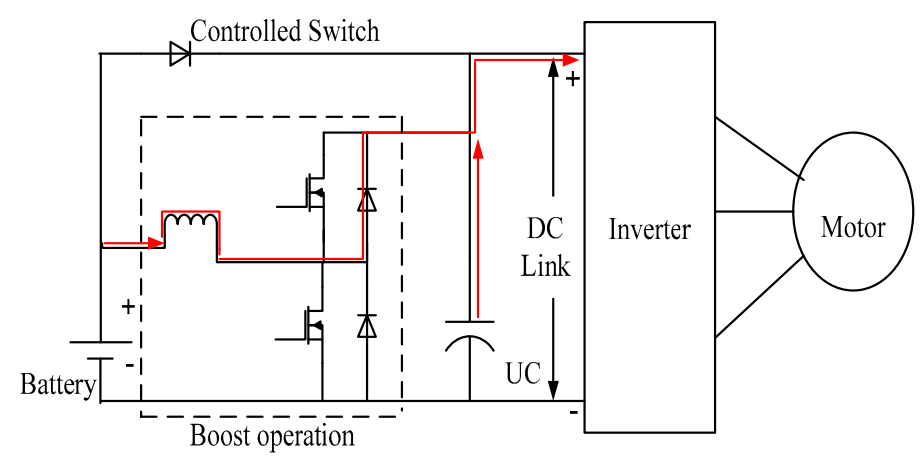

Figure 7. Acceleration mode.

Mode-4: Deceleration

( $\mathrm{V}_{\mathrm{UC}}$ is the terminal voltage of the ultracapacitor and $\mathrm{V}_{\mathrm{UC} \_}$target is the maximum charging voltage of the capacitor.)

This mode (Figure 8) is also called regenerative braking because in this mode the UC starts to charge, and the DC/DC converter is in boost operation (or there is no operation). Converter operation is totally dependent upon the target $\mathrm{UC}$ voltage $\left(\mathrm{V}_{\mathrm{UC} \_ \text {target }}\right)$.

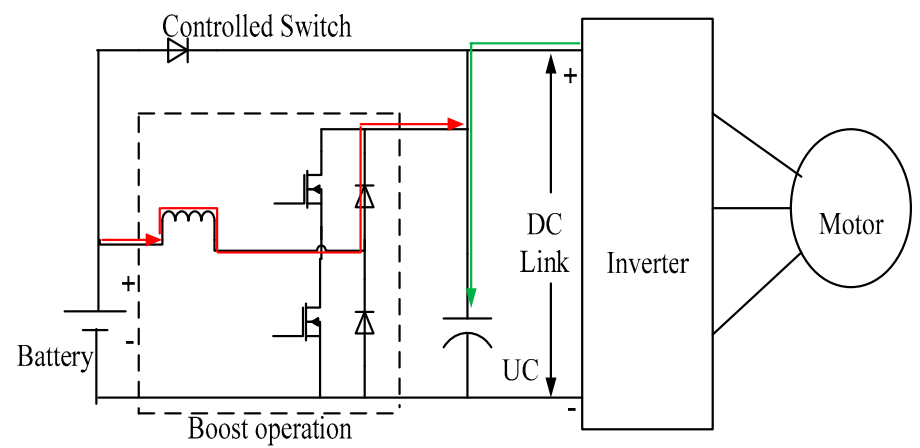

Figure 8. Regenerative braking when $\mathrm{V}_{\mathrm{UC}}<\mathrm{V}_{\mathrm{UC} \text { _target }}$.

In continuous decelerating mode (Figure 9) the DC/DC converter goes into buck operation, thereby transferring the energy from the UC to the battery [16]. During regenerative braking, the ultracapacitor recovers energy from the motor in a negligible time on the order of $0.2-3 \mathrm{~s}$. The DC/DC converter transfers this energy recovered by UC with a controlled rate of charging of the battery.

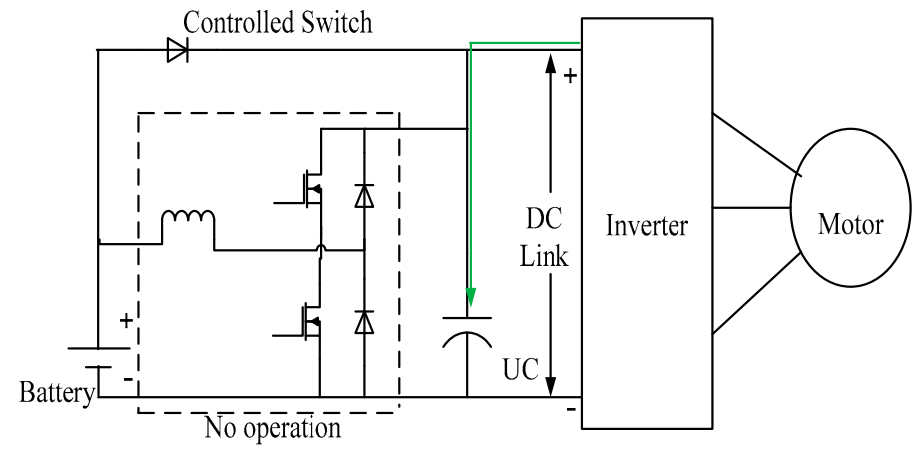

Figure 9. Regenerative braking when $\mathrm{V}_{\mathrm{UC}}>\mathrm{V}_{\mathrm{UC} \_ \text {target }}$.

\subsubsection{Multiple DC/DC Converter Design}

The battery and UC are connected through separate converters (Figure 10); one is current-controlled and connected at the output side of the battery, whereas the other is voltage-controlled and connected 
at the UC side. The outputs of both these converters are the same as the DC link [16,17]. In this design, it is possible to maintain a voltage level below the DC link voltage. The main advantage of this design is that the UC is utilized to the best possible extent. On the other hand, the drawback of this design is that it requires two full bridge converters, thus resulting in an increase in the overall size and cost of ESS $[18,19]$.

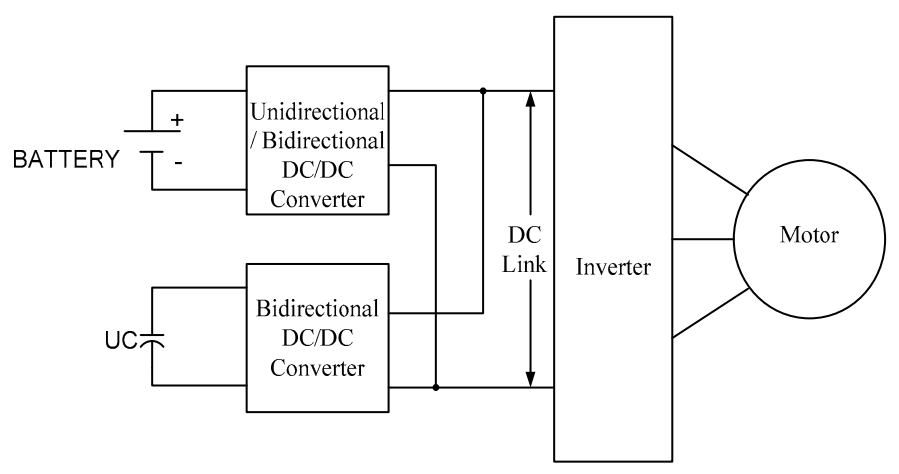

Figure 10. Multiple DC/DC converter design.

\subsubsection{UC/Battery with Inverter Design}

Basic topologies are implemented using multisource connected to load through a DC/DC converter. In the proposed topology, an inverter-fed AC link is used to connect the battery and the ultracapacitor via the space vector pulse width modulation technique (Figure 11). The design reduces the size and weight of the system.

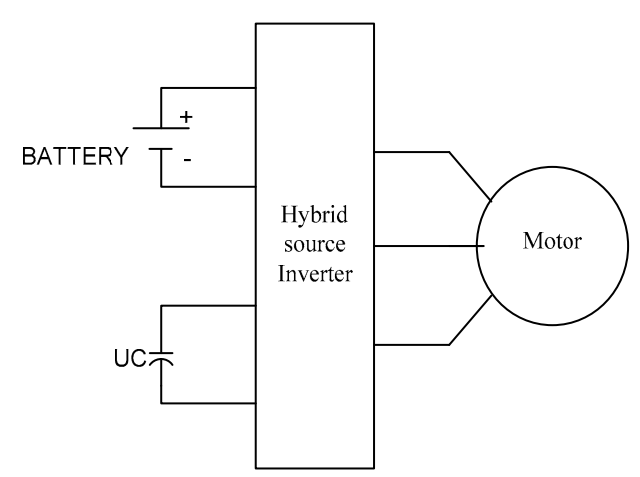

Figure 11. UC/battery with inverter design.

Hardware for the UC/battery design simulated and implemented to validate the design.

\section{Materials and Methods}

To understand the charging and discharging behavior of the ultracapacitor, a simulation is carried out in the MATLAB environment as follows.

\subsection{Basic Simulation Work}

To validate the dynamic response of the ultracapacitor, the simulation is carried out in a MATLAB environment wherein the battery is directly connected to the DC link and the ultracapacitors connected to the DC link via a DC/DC converter. To understand the basic analogy of hybridization, a simulation for design 1.2 (a DC/DC converter based on UC/battery design) was chosen. In this design the resistive load is increased gradually over time [15].

A $12 \mathrm{~V}$ battery voltage $\left(V_{B}\right)$ with $50 \mathrm{Ah}$ is selected with a $12 \mathrm{~V}, 20$ Farad ultracapacitor. Three resistive loads with time delays are connected for loading purposes and low charge protection is provided with 
control switches. The results (Figure 12) are obtained from the Simscope tool in MATLAB along with Simulink. The total simulation time is $1000 \mathrm{~s}$.

The resistive load comes into the circuit at time steps of $300 \mathrm{~s}, 400 \mathrm{~s}$, and $700 \mathrm{~s}$. During the dynamic change of the load, the peak load is shared by the ultracapacitor (12 Farad) and the battery. The simulation results reveal that the battery discharging starts at $320 \mathrm{~s}$ with a small reduction in the battery terminal voltage $\left(V_{B}\right)$ due to the internal resistance of battery; the current obtained is $2 \mathrm{~A}$.

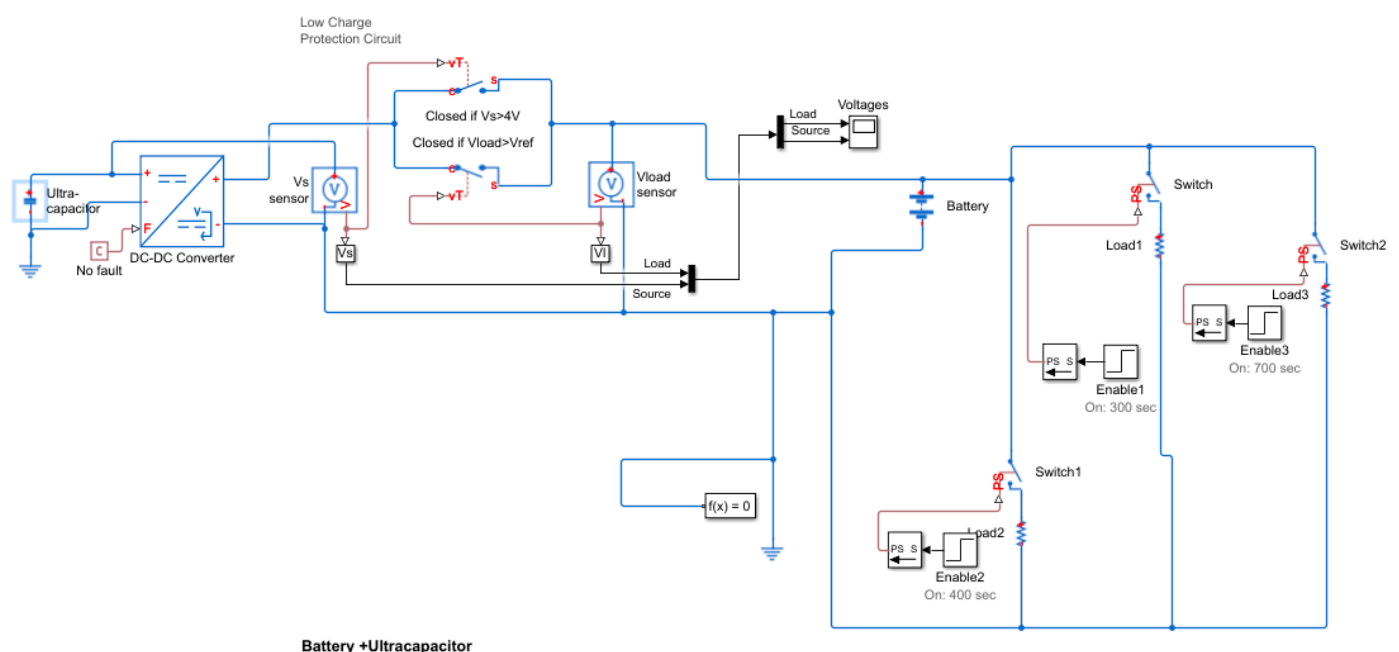

Figure 12. Simulink model of energy management system.
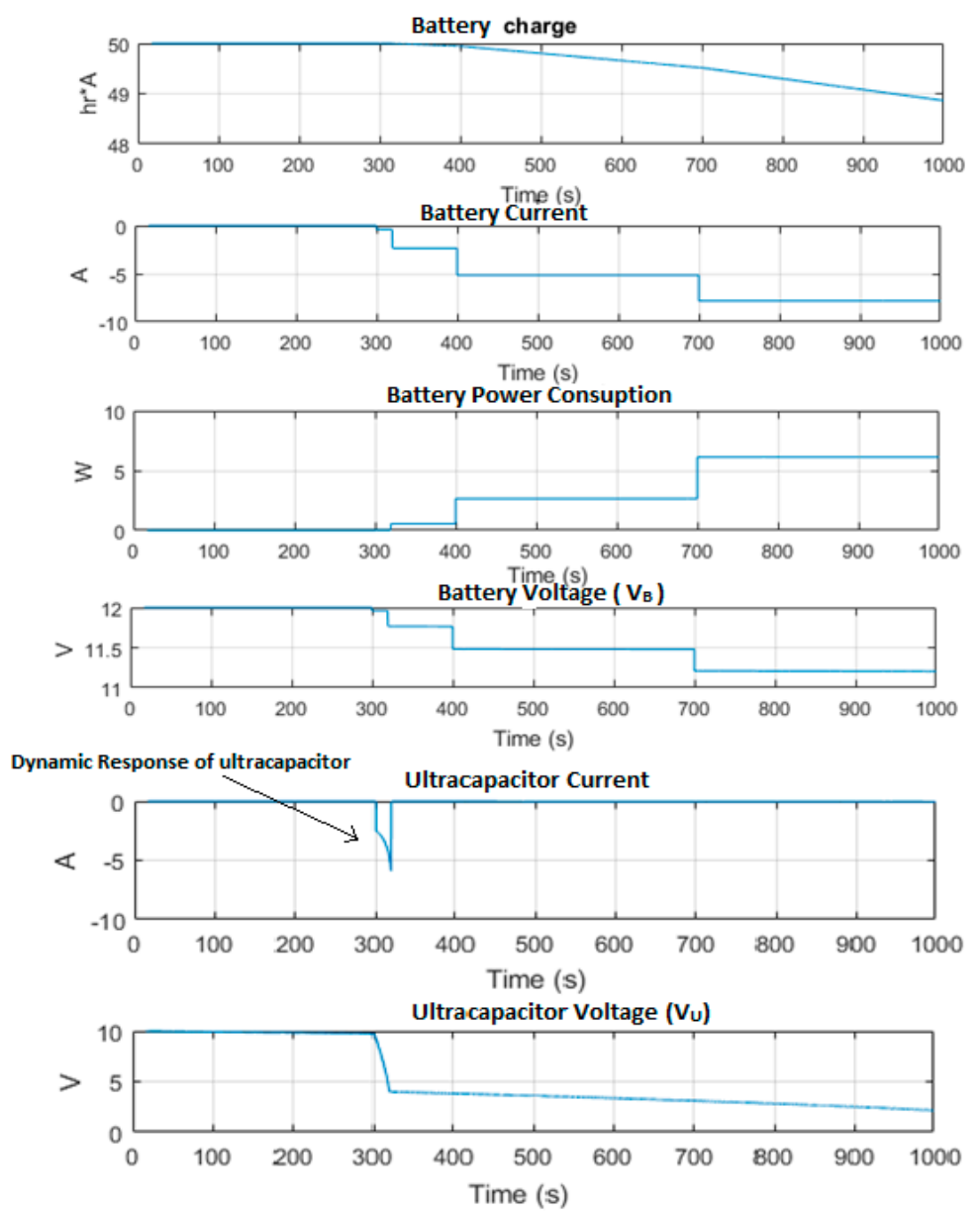

Figure 13. Battery charge, current, power and ultra-capacitor current, voltage characteristics. 
The dynamic change in load demand is shared by UC, (Figure 13), thereby maintaining the DC link voltage.

In the basic simulation, it is observed that at the peak power requirements of the load, the ultracapacitor provides the power requirements dynamically (at $t=300 \mathrm{~s}$ ).

\subsection{Proposed Work}

Energy storage system of plug-in EV as an active power source [18-20]:

A hybridized source (battery + ultracapacitor) is used to fulfill the dynamic requirements of the motor. The dynamic power demands can be fulfilled using a combination of a battery and an ultracapacitor in an energy storage system of electric vehicle (EV). Real power $(P)$ and reactive power $(Q)$ can be injected or absorbed from the load. When this vehicle is used as a plug-in vehicle, this phenomenon of power control enhances the smartness of the grid. During EV working, power from an energy storage system is injected into the electrical propulsion system (here a three-phase voltage source inverter-fed motor is used). Driving conditions associated with torque reflect on the motor current. The driving cycle is simulated by using load as induction motor drive. Energy sharing between the battery and ultracapacitor is observed using the PSIM software environment.

The circuit consists of two separate inverters connected to the battery and ultracapacitor. SVPWM (Space Vector Pulse Width Modulation) is used to control the various circuit parameters. AHESS uses a multi-source inverter to connect the battery and ultracapacitor directly to the three-phase smart grid when the vehicle is idle, and the same system connects to the load during prolusion without adding a DC/DC converter. Elimination of the DC/DC converter enhances the compactness. The battery life depends on the peak power demand of the load. This peak power requirement is in turn fulfilled by connecting the ultracapacitor along with a battery. Here the specific energy demand and the peak power demand for HEV are provided by the battery and the ultracapacitor, respectively. In addition, the benefits of this new battery/ultracapacitor topology are a reduction in the size and hence in the overall cost of the energy storage system, along with improved life, endurance, and efficiency of the system. The HESS system was studied in depth and analyzed using a PSIM environment-based simulation, the results of which are discussed below.

\section{Simulation Results and Discussion}

The simulation consisted of an inverter-fed AC load (induction motor) (Figure 14), wherein a novel inverter is connected to an AC link. The battery (voltage $=24$ volts) source feeds inverter- 1 , whereas the ultracapacitor (300 Farad, 24 volts) feeds inverter-2. The simulation depicts the characteristics of power sharing between the battery and ultracapacitor.

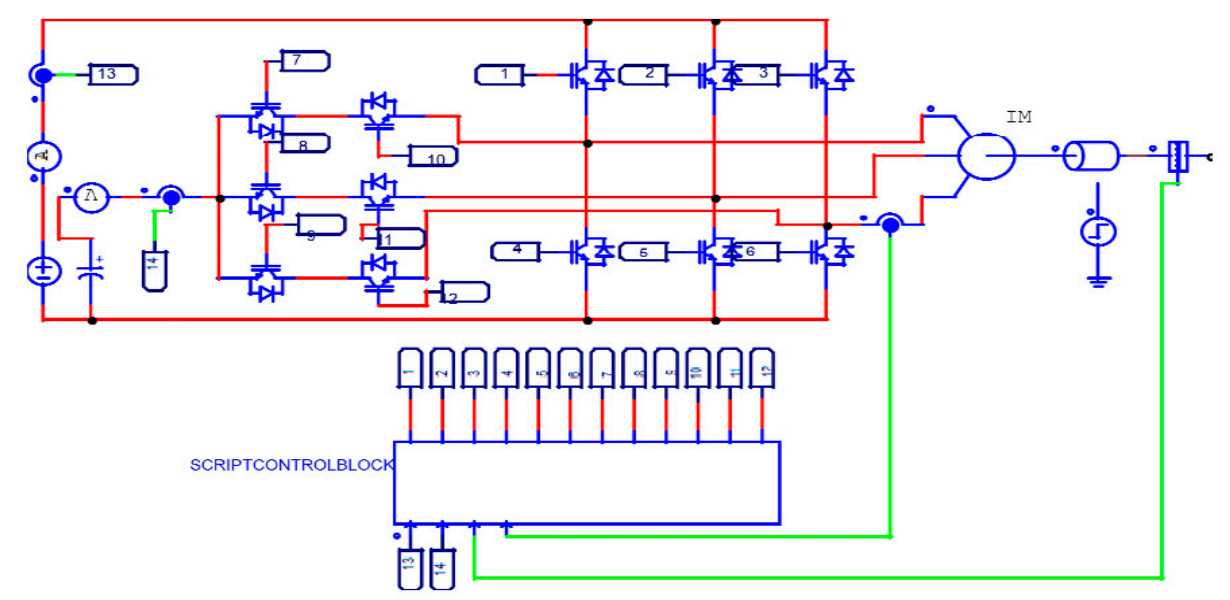

Figure 14. Simulation of a hybrid inverter with load (induction motor) [18,19]. 
The main feature of this simulation is the use of a space vector analogy using a PSIM Script file. Using script control block, control signals are obtained. Current and torque feedbacks are taken from the sensors. The two DC sources are designed using an ideal battery and ultracapacitor source. A multisource inverter is designed with IGBTs. The load is designed by a three-phase induction motor. As the induction motor itself is the balanced load, the phase current of one phase is sensed by the current sensor; the shaft speed is also sensed. The simulation time selected is $2 \mathrm{~s}$.

This simulation shows P-Q control in load (induction motor). Considering inductive load, the power factor of the motor is lagging. The simulation results indicate the active and reactive power requirements of the load.

- $\quad$ Active power $(\mathrm{P})$ with positive magnitude is the power flowing from the DC bus to the load.

- Reactive power $(\mathrm{Q})$ in Var with positive magnitude is reactive power being supplied to the load.

- Bidirectional power flow in any combination is possible, where negative magnitudes inject active and reactive power from the DC bus to the load.

\subsection{PSIM Simulation Results}

Simulation is carried out for the following modes.

There are three operating modes corresponding to the switching states [21-26]:

- Mode-1 (Battery and Motor or RL load): In this mode, $V_{B}$ drives the motor/RL load and $V_{U}$ is not used.

- Mode-2 (Battery, Ultracapacitor and Motor or RL load): In this mode, $V_{B}$ drives the load (for motor or grid) by charging the ultracapacitor $\left(V_{U}\right)$. The effective output voltage is equal to $\left(\mathrm{V}_{\mathrm{B}}-\mathrm{V}_{\mathrm{U}}\right)$.

- Mode-3 (Ultracapacitor and Motor/ RL load): Here, $V_{B}$ is not used; the ultracapacitor alone $\left(V_{U}\right)$ drives the motor.

Simulation results for all modes are discussed below:

\subsubsection{Mode-1 (Battery \& Motor or RL Load)}

In mode-1 (Figure 15), the motor operates on $24 \mathrm{~V}$ battery input via an inverter. The basic inverter mode is observed through simulation results with a simulation time of $1 \mathrm{~s}$.

Inverter-1
Output
Voltage

Inverter-1

Output

Current
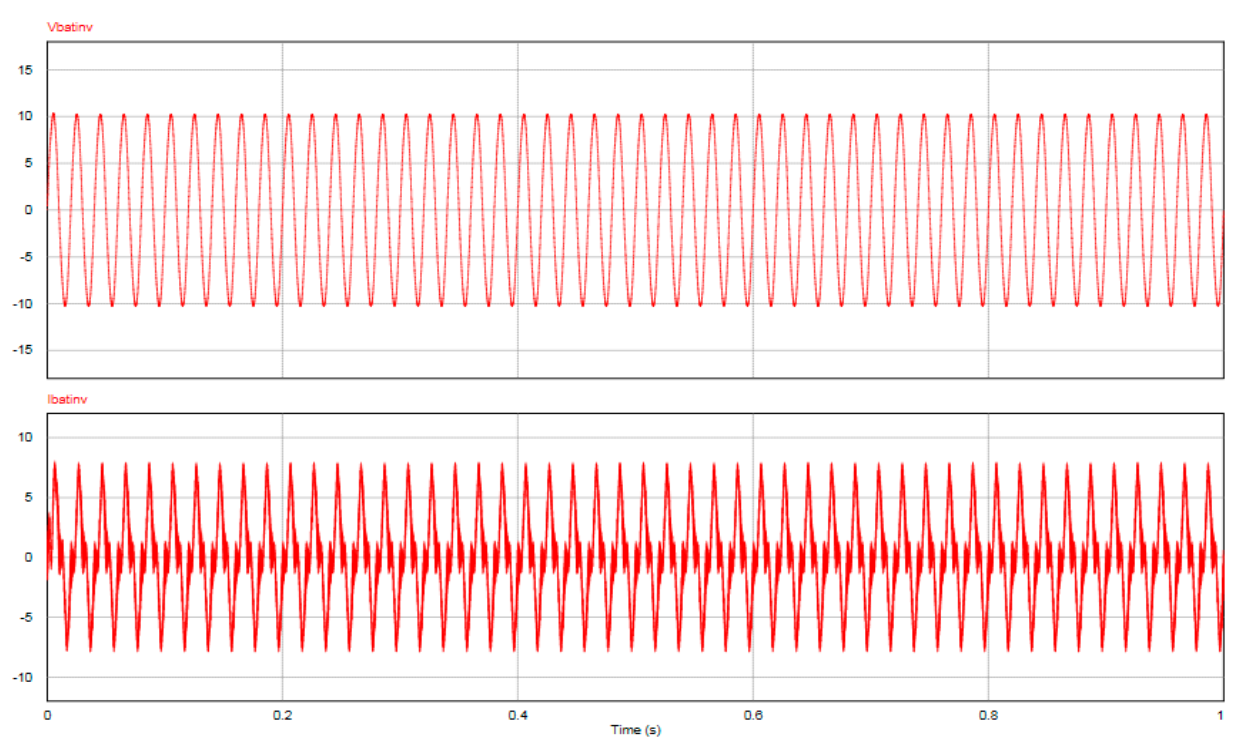

Figure 15. For mode-1 inverter 1 output (fed by battery). 
As the above results show that the magnitude of power is in the positive direction, active and reactive power are injected towards the motor (Figure 16).

Active

Power

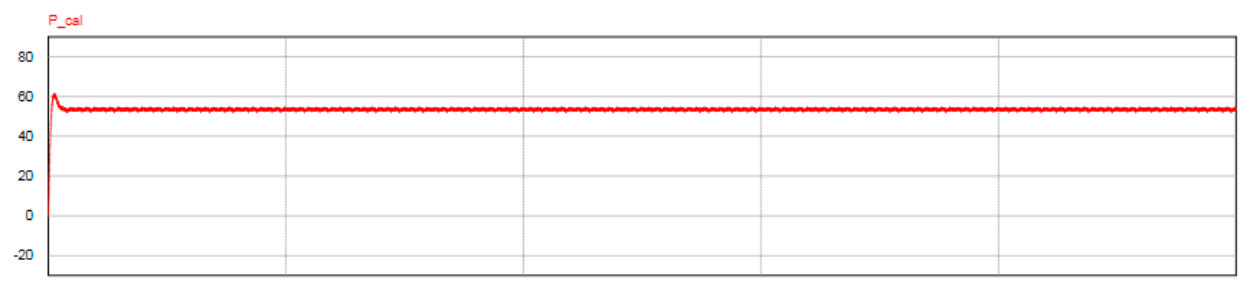

Reactive

Power

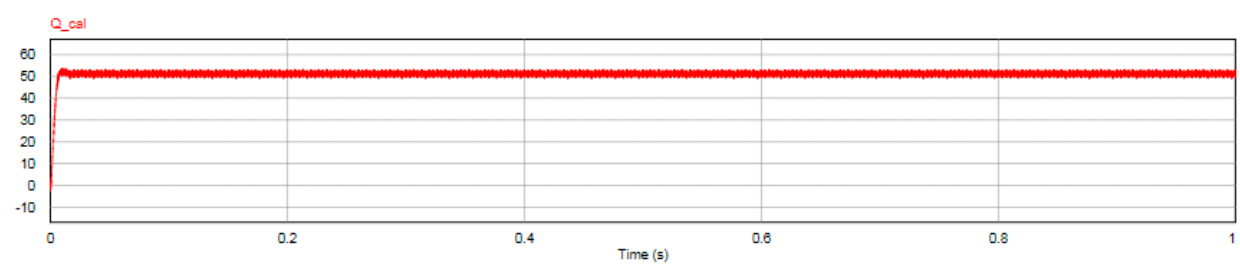

Figure 16. For mode-1: active and reactive power consumed.

Mode-2 is the mixed mode, where the motor is driven by the battery and ultracapacitor via an inverter.

\subsubsection{Mode-2 (Battery, Ultracapacitor \& Motor or RL Load)}

Simulation is carried out for1s. At $t=0.3 \mathrm{~s}$, the load reference is increased. As the dynamics of ultracapacitor are fast, the ultracapacitor shares the peak power demand, which reduces the current stress during peak power requirements.

From the waveform (Figures 17 and 18), it is evident that the ultracapacitor gets discharged in load at $0.3 \mathrm{~s}$. Current stress on the battery is shared by the ultracapacitor.

Inverter-1

(battery

connected)

Voltage

Inverter-1

(battery

connected)

Current
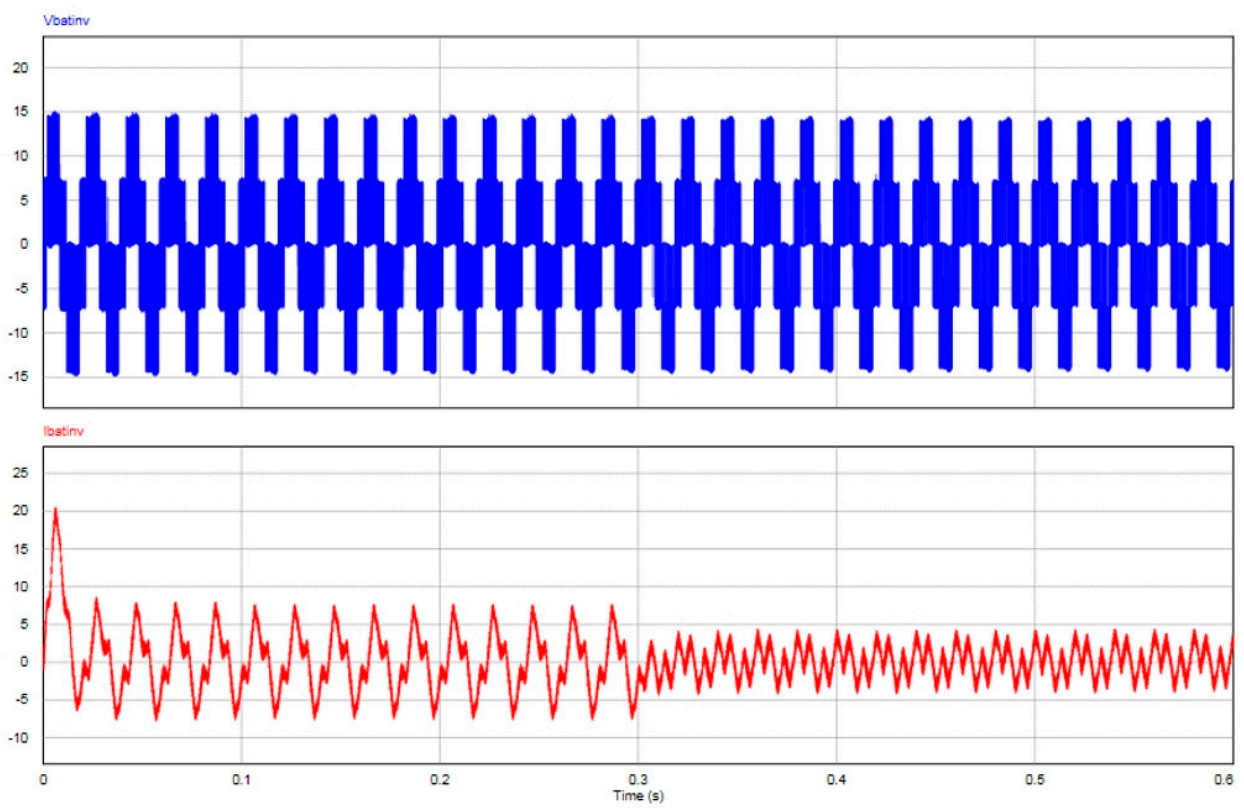

Figure 17. Inverter-1 voltage and current output. 


\section{Ultracapacitor voltage During dynamic power requirement. $0.3 \mathrm{sec}$}

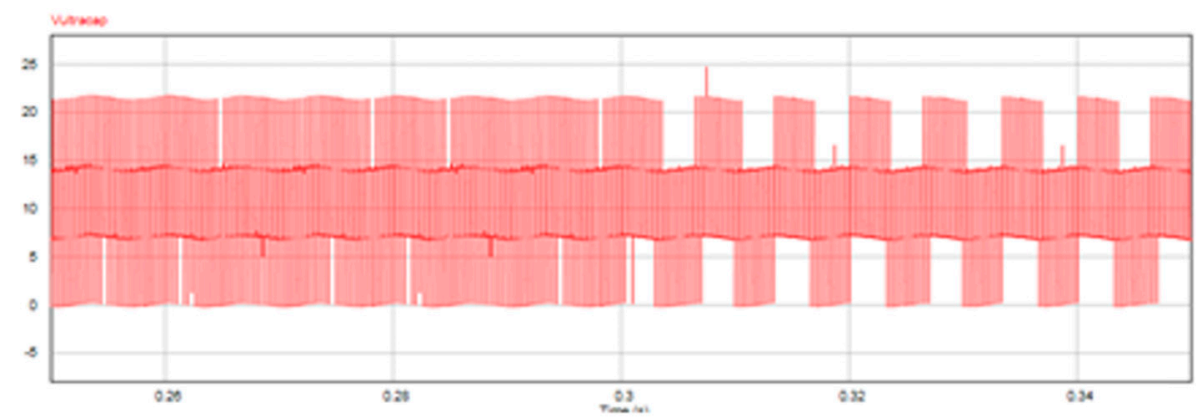

Figure 18. Ultracapacitor terminal voltage.

Reference currents in Figure 19 generated from the abc reference frame are converted to a dq reference frame transformation, which decides the power sharing. The ultracapacitor and battery both provide power to the load (induction motor/grid) during the simulation period.

\section{Active}

power
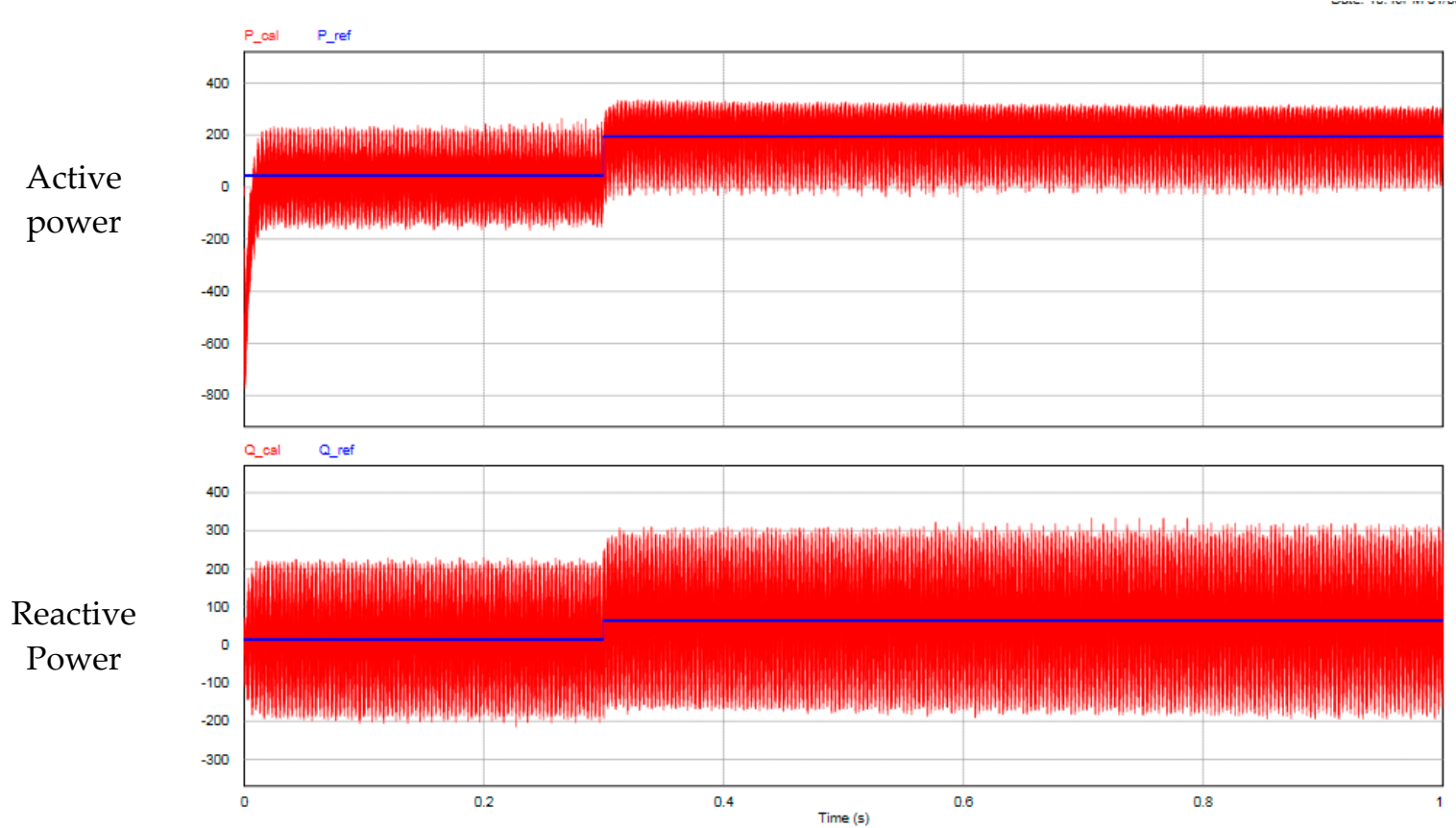

Figure 19. Active and reactive power (reference vs. calculated).

\subsubsection{Mode-3 (Ultracapacitor and Motor/RL Load)}

In mode-3, fast dynamics of the ultracapacitor is observed. We can use the ultracapacitor as a source with respect to motor connection [21]. Sharing of power during operation is observed with these characteristics (Figure 20). At $0.3 \mathrm{~s}$ the load reference is increased, which initializes the power sharing of ultracapacitor and the battery.

As per the simulation results, (Figures 21 and 22), it is observed that mode-2 reduces the stress on the battery with simultaneous use of an ultracapacitor. Validation is carried out with a small prototype using a combination of the battery and ultracapacitor controlled with a novel hybrid-type inverter. In the next section the design, operation, experimentation, and results are elaborated upon. 


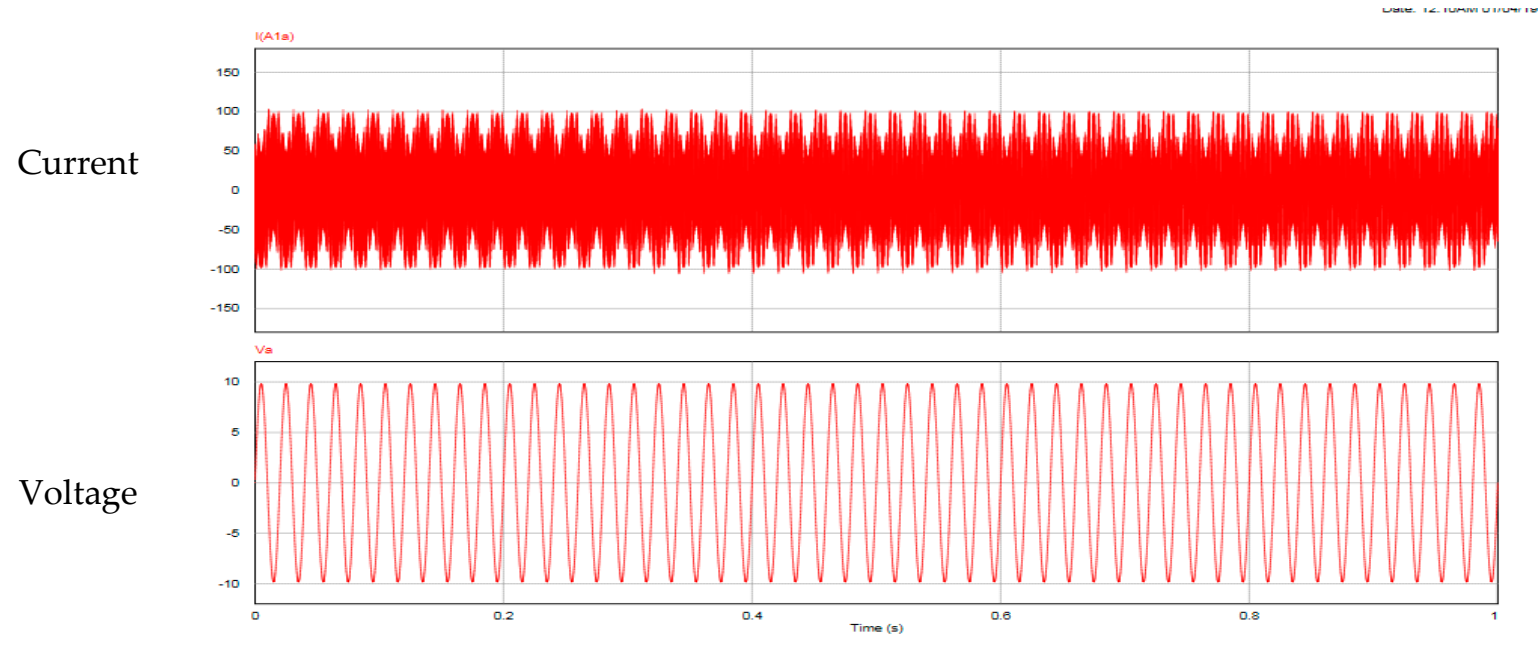

Figure 20. Inverter output voltage and current.

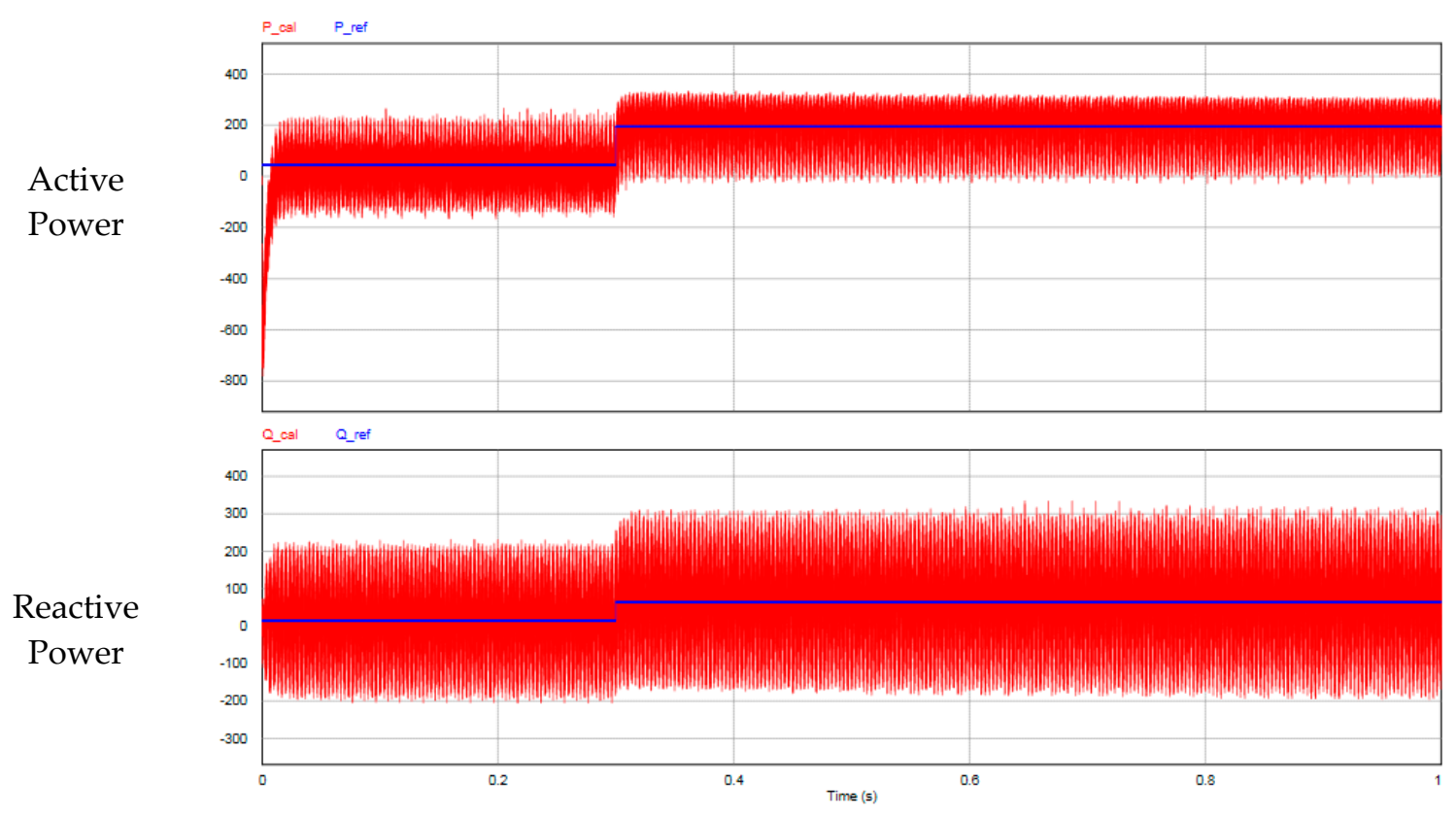

Figure 21. Active and reactive power (reference vs. calculated).

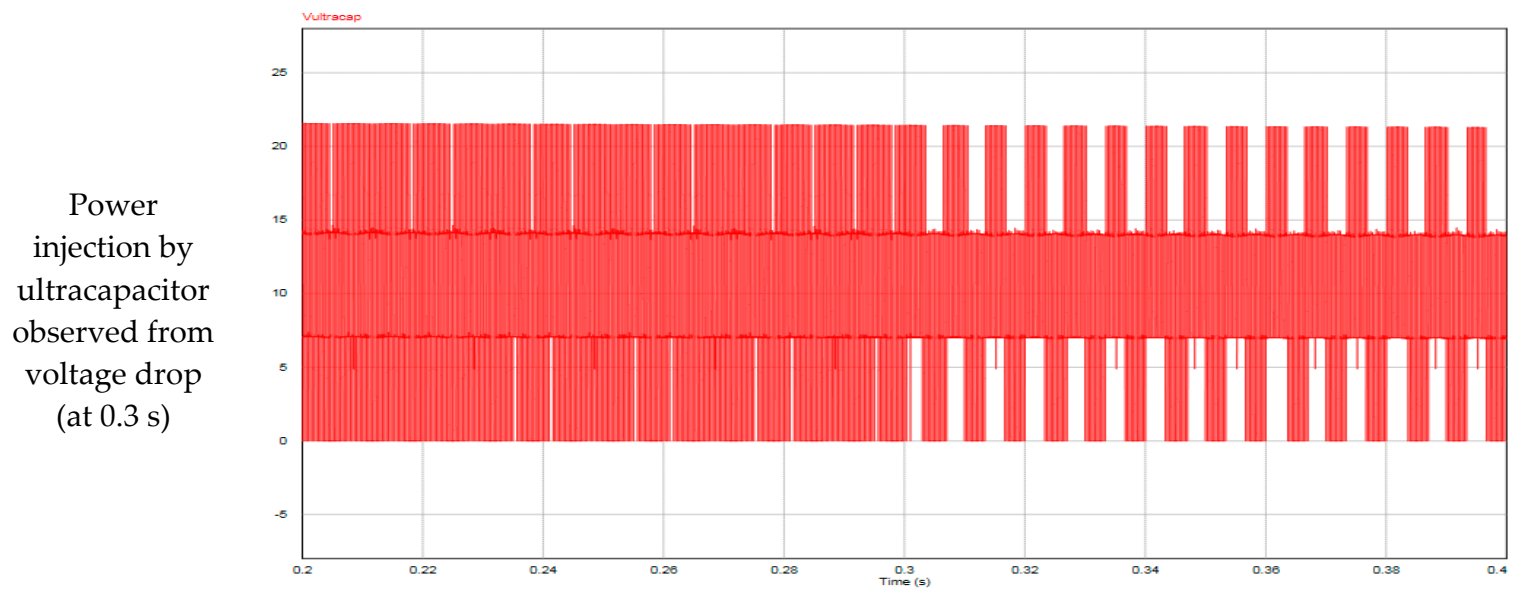

Figure 22. Ultracapacitor voltage. 


\section{Hardware Implementation}

The main purpose of this topology (Figure 23) is to cascade several DC sources to the three-phase AC motor. In this case, two DC sources, namely the battery $\left(\mathrm{V}_{\mathrm{B}}\right)$ and ultra-capacitor $\left(\mathrm{V}_{\mathrm{U}}\right)$, are connected. The main advantage of this topology is that it does not add any additional stages between the motor and the sources, which results in an improved response of electric vehicle by enhancing energy and power demand fulfilment. In the proposed control strategy, the source current is controlled according to the torque requirements of the driving cycle. In a closed-loop system three switching modes are selected according to the power requirements of the grid or the acceleration, cruising, and braking of an electric vehicle [13]. Here the modes are selected with open-loop control and to observe the characteristics during the sharing of sources.

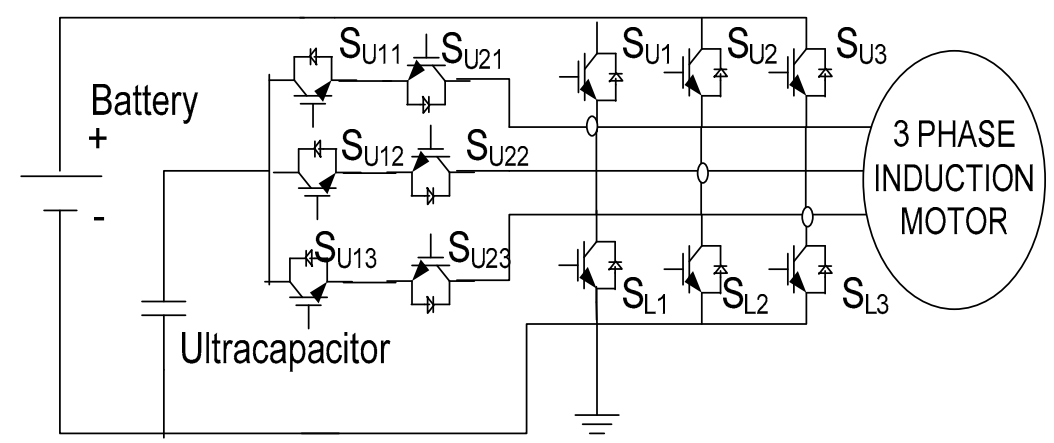

Figure 23. Power circuit $[13,14]$.

There are three operating modes corresponding to the switching states:

- $\quad$ Mode-1: The switches $\mathrm{S}_{\mathrm{U} 1}, \mathrm{~S}_{\mathrm{U} 2}, \mathrm{~S}_{\mathrm{U} 3}$, and $\mathrm{S}_{\mathrm{L} 1}, \mathrm{~S}_{\mathrm{L} 2}, \mathrm{~S}_{\mathrm{L} 3}$ enable the discharging of the battery $\left(\mathrm{V}_{\mathrm{B}}\right)$ to supply the motor (RL load); an ultra-capacitor $\left(\mathrm{V}_{\mathrm{U}}\right)$ is not used. (The ultra-capacitor is charged through the battery using switches $\mathrm{S}_{\mathrm{U} 21}, \mathrm{~S}_{\mathrm{U} 22}, \mathrm{~S}_{\mathrm{U} 23}$ along with switches $\mathrm{S}_{\mathrm{U} 1}, \mathrm{~S}_{\mathrm{U} 2}$, $\mathrm{S}_{\mathrm{U} 3}$ in closed-loop control by sensing the load current and terminal voltage of the ultra-capacitor; see Figure 24).

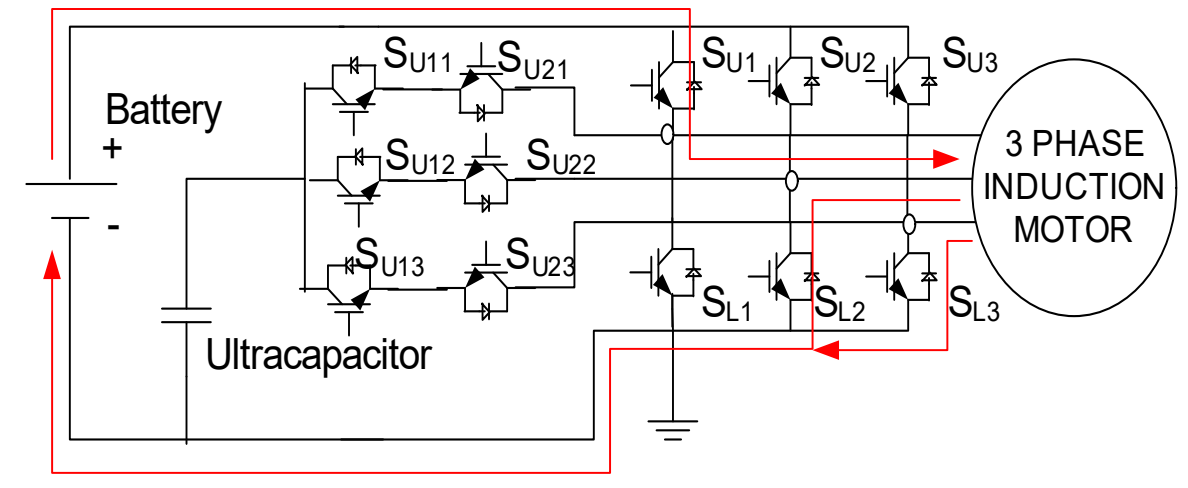

Figure 24. Operation of circuit under mode-1.

- Mode-2: The switches $\mathrm{S}_{\mathrm{U} 1}, \mathrm{~S}_{\mathrm{U} 2}, \mathrm{~S}_{\mathrm{U} 3}$ and $\mathrm{S}_{\mathrm{U} 11}, \mathrm{~S}_{\mathrm{U} 12}, \mathrm{~S}_{\mathrm{U} 13}$ enable the battery $\left(\mathrm{V}_{\mathrm{B}}\right)$ to supply the motor (RL load) with discharging ultracapacitor $\left(\mathrm{V}_{\mathrm{U}}\right)$ (Figure 25). 


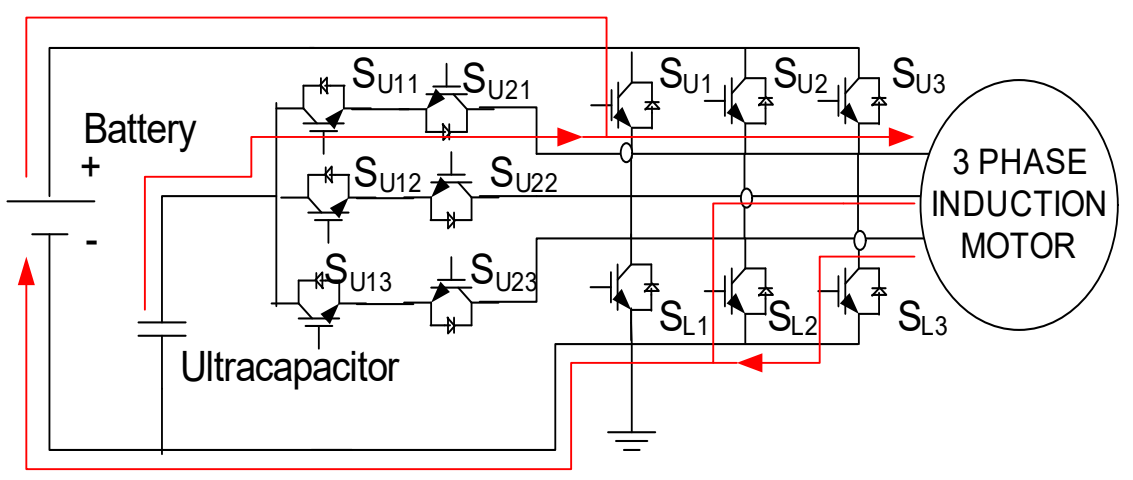

Figure 25. Operation of circuit under mode-2.

The phase voltages $\left(\mathrm{V}_{10}, \mathrm{~V}_{2} \mathrm{O}, \mathrm{V}_{3 \mathrm{O}}\right)$ are functions of the state of the switches and input voltages:

$$
\begin{aligned}
& V_{1 O}=E_{S U 1} V_{B}+E_{U 11} V_{U}-Z_{a} i_{1} \\
& V_{2 O}=E_{S U 2} V_{B}+E_{U 12} V_{U}-Z_{b} i_{2} \\
& V_{3 O}=E_{S U 3} V_{B}+E_{U 13} V_{U}-Z_{C} i_{3}
\end{aligned}
$$

where $\mathrm{Z}$ = impedance of load and

$$
\mathrm{E}_{\mathrm{SU} 1,2,3} \text { and } \mathrm{E}_{\mathrm{U} 11,12,13}=\text { switching functions }
$$

Similarly input currents $\left[\mathrm{I}_{\mathrm{B}}, \mathrm{I}_{\mathrm{U}}\right]$ can be expressed as:

$$
\begin{aligned}
& I_{B}=E_{S U 1} \cdot i_{1}+E_{S U 2} \cdot i_{2}+E_{S U 3} \cdot \dot{i}_{3} \\
& I_{U}=E_{U 11} \cdot \dot{i}_{1}+E_{U 12} \cdot \dot{i}_{2}+E_{U 13} \cdot i_{3} .
\end{aligned}
$$

- Mode-3: The battery $\left(\mathrm{V}_{\mathrm{B}}\right)$ is not used and switches $\mathrm{S}_{\mathrm{L} 1}, \mathrm{~S}_{\mathrm{L} 2}, \mathrm{~S}_{\mathrm{L} 3}$, and $\mathrm{S}_{\mathrm{U} 11}, \mathrm{~S}_{\mathrm{U} 12}, \mathrm{~S}_{\mathrm{U} 13}$ enable the ultracapacitor $\left(\mathrm{V}_{\mathrm{U}}\right)$ to supply the motor (RL load) (Figure 26).

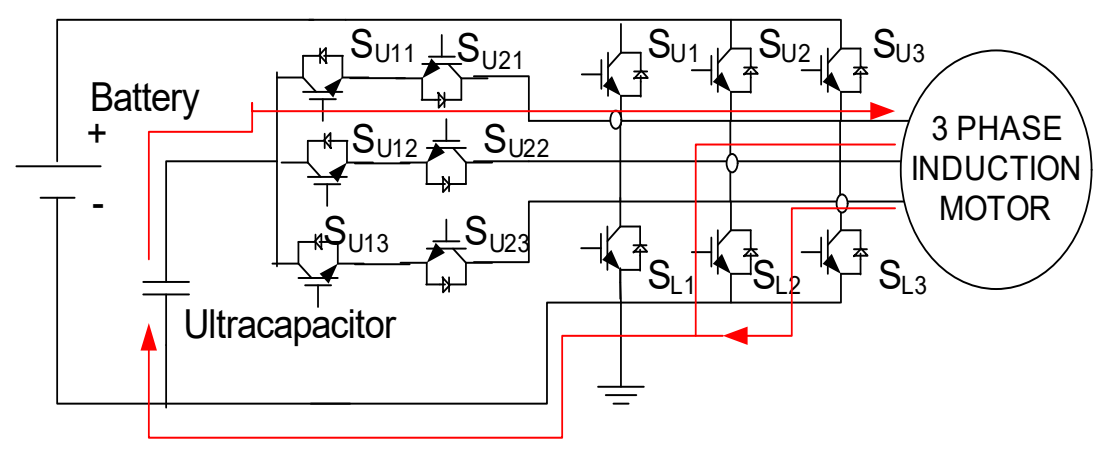

Figure 26. Operation of circuit under mode-3.

The hardware consists of the Buffer IC (74HC244) to control modes with an adjustment of the duty cycle using the enable signal. EN1 is used to control upper switches $\mathrm{S}_{\mathrm{U} 1}, \mathrm{~S}_{\mathrm{U} 2}, \mathrm{~S}_{\mathrm{U} 3}$. EN2 controls $\mathrm{S}_{\mathrm{L} 1}$, $\mathrm{S}_{\mathrm{L} 2}, \mathrm{~S}_{\mathrm{L} 3}$, whereas EN1* and EN2* are used to control $\mathrm{S}_{\mathrm{U} 11}, \mathrm{~S}_{\mathrm{U} 12}, \mathrm{~S}_{\mathrm{U} 13}$, and $\mathrm{S}_{\mathrm{U} 21}, \mathrm{~S}_{\mathrm{U} 22}, \mathrm{~S}_{\mathrm{U} 23}$, respectively. A low state (digital zero) of latch allows input at latch output (Figure 27). The simulation is carried out using the Proteus Design Suite environment [27-29]. 


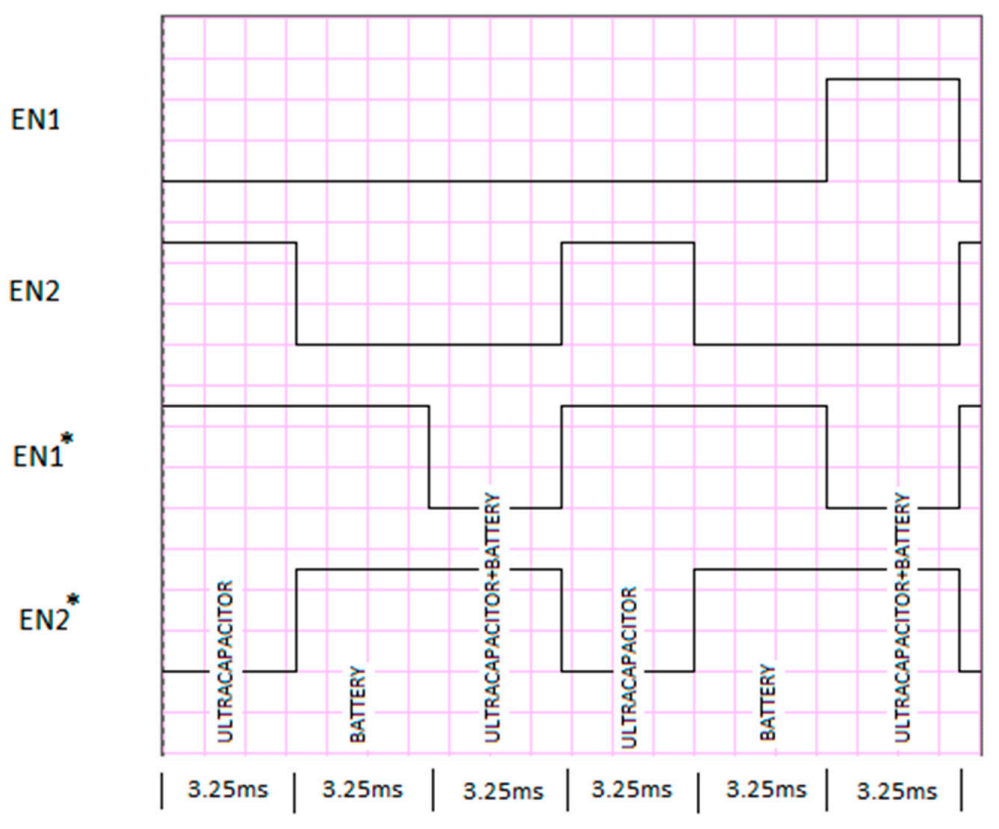

Figure 27. Mode control using the buffer.

MOSFET switches are controlled through latch, explained as Table 4.

Table 4. Latch and switch enable States for modes-1,2, and 3.

\begin{tabular}{ccccc}
\hline Control State & EN1 $\left(\mathrm{S}_{\mathrm{U} 1}, \mathrm{~S}_{\mathrm{U} 2}, \mathrm{~S}_{\mathrm{U} 3}\right)$ & $\mathrm{EN} 2\left(\mathrm{~S}_{\mathrm{L} 1}, \mathrm{~S}_{\mathrm{L} 2}, \mathrm{~S}_{\mathrm{L} 3}\right)$ & $\mathrm{EN1} *\left(\mathrm{~S}_{\mathrm{U} 11}, \mathrm{~S}_{\mathrm{U} 12}, \mathrm{~S}_{\mathrm{U} 13}\right)$ & $\mathrm{EN2} *\left(\mathrm{~S}_{\mathrm{U} 21}, \mathrm{~S}_{\mathrm{U} 22}, \mathrm{~S}_{\mathrm{U} 23}\right)$ \\
\hline UC (Charging) & $\mathrm{ON}$ & $\mathrm{OFF}$ & $\mathrm{OFF}$ & $\mathrm{ON}$ \\
Battery (Discharging) & $\mathrm{ON}$ & $\mathrm{ON}$ & $\mathrm{OFF}$ & OFF \\
Battery (Discharging) + & $\mathrm{ON}$ & $\mathrm{ON}$ & $\mathrm{ON}$ & OFF \\
UC (Discharging) & & & & \\
\hline
\end{tabular}

Switch control through the SVPWM (Space Vector Pulse Width Modulation) technique is shown in Figure 28.

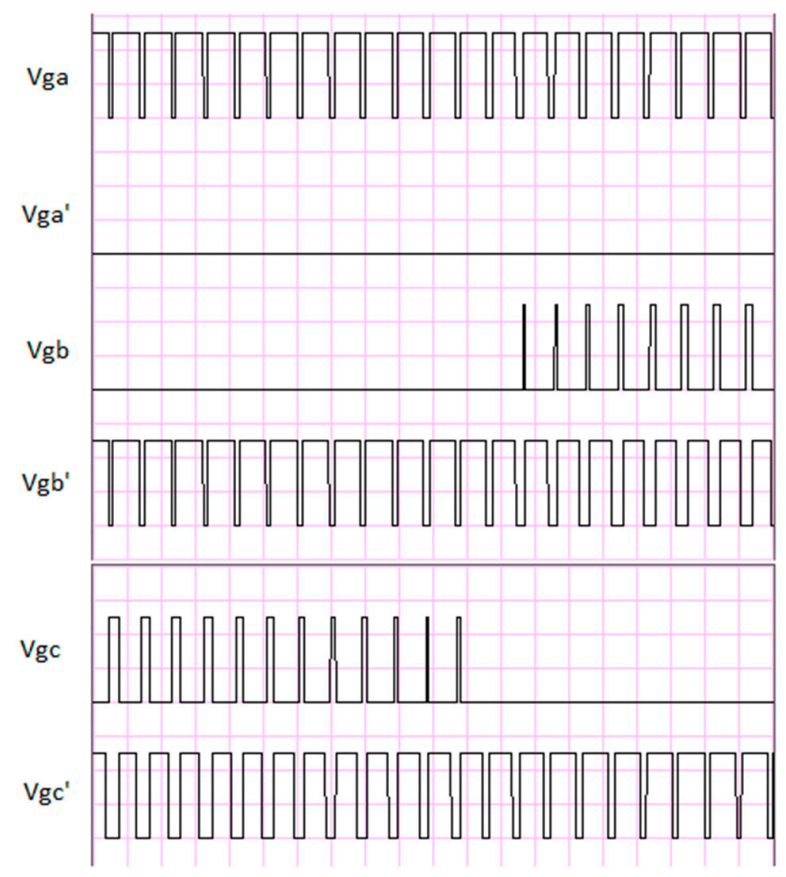

Figure 28. Space Vector Pulse Width Modulation (SVPWM) control signal generation in protease. 
The operation of the circuit is explained with a flowchart (Figure 29) as follows.
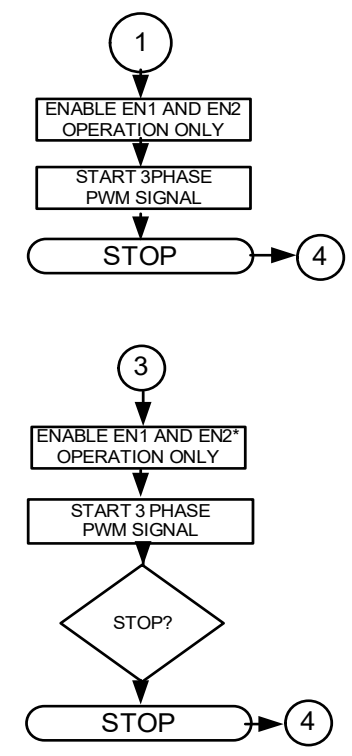

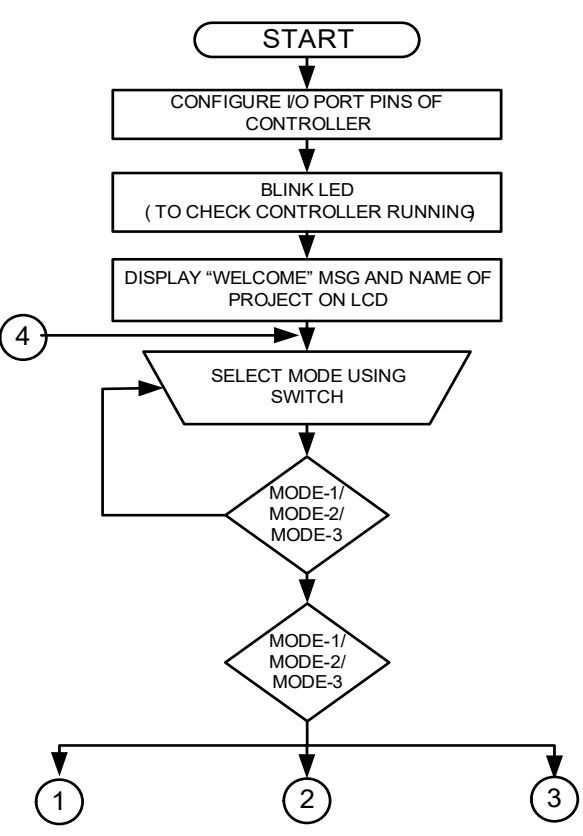

Figure 29. Process chart.

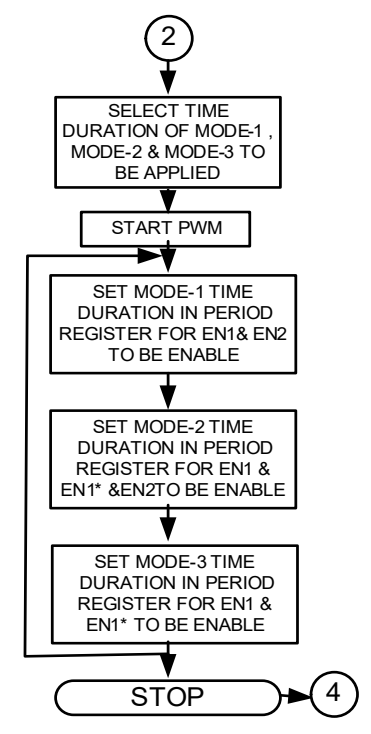

In hardware implementation, the battery and ultracapacitor drive the load (Motor/Grid/RL Load); we observe the power and energy sharing during dynamic loading situations. The observations are carried out for different combinations of three modes (i.e., mode-1: Battery only as a source; mode-2: Both sources acting simultaneously, handling the dynamic power requirement situation; and mode-3: Ultracapacitor as a source).

Hardware is implemented using six IGBTs, which constitute the three-phase inverter, supplying battery power to the AC link and an ultracapacitor bank connected to AC link through six IGBTs. Thus, a total 12 IGBTs are used in the implementation.

Hardware was implemented (Figure 30) based on three modes, as stated previously. Using express PCB software, the PCB was designed.

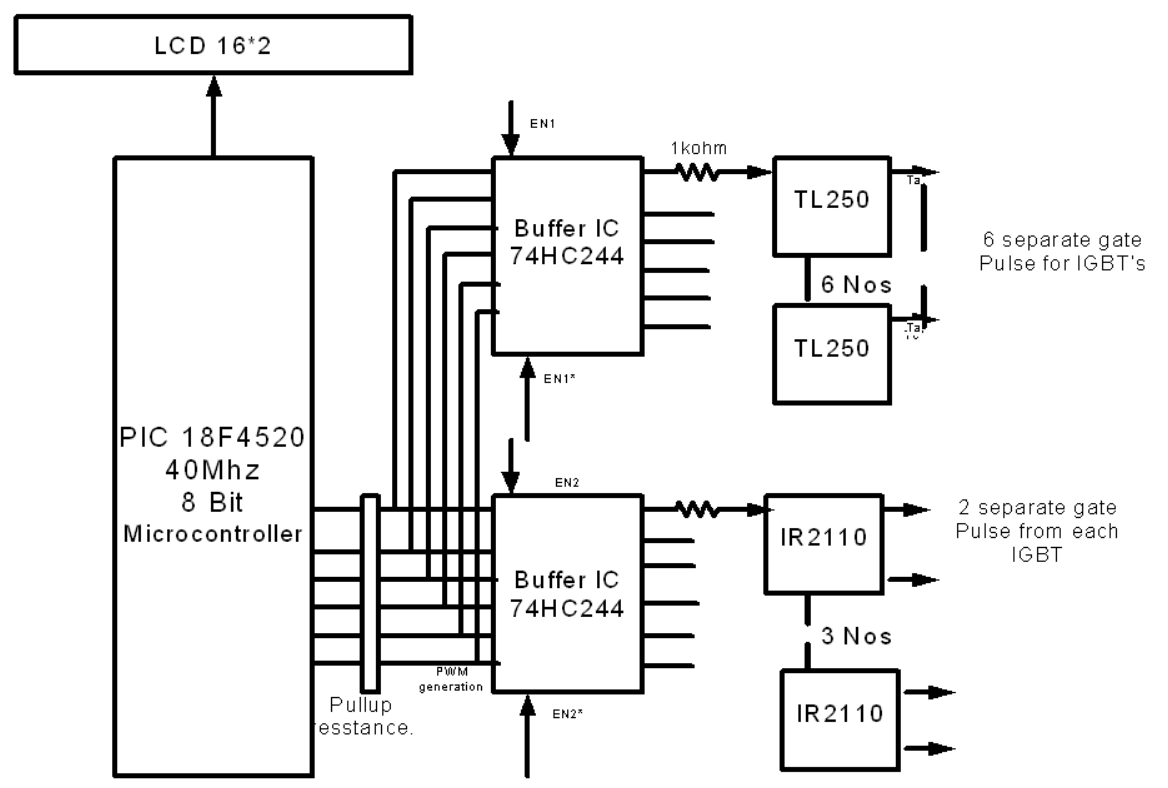

Figure 30. Hardware implementation. 
A single-side PCB was etched and prepared with fixing components (Figure 31). The microchip processor 18F4520 was used with a control strategy based on the lookup table, with signal generation using the SVPWM analogy. Digital control signals were developed within six sectors using dqo vectors (Figure 32 and Table 5).

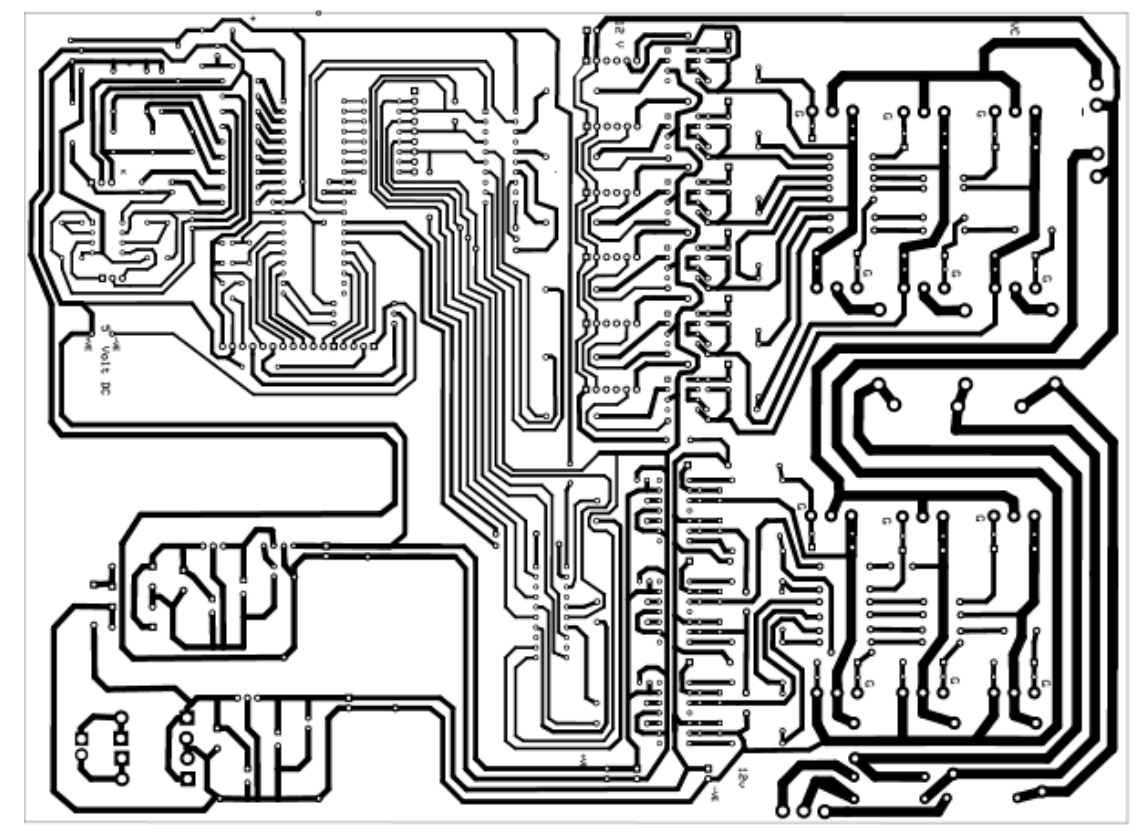

Figure 31. PCB (Printed Circuit Board) layout.

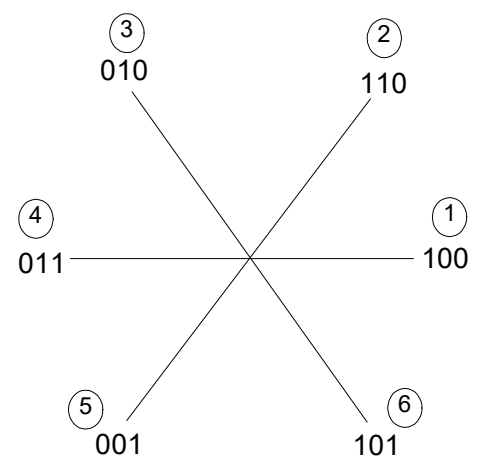

Figure 32. SVPWM analogy.

Table 5. Space Vector Pulse Width Modulation (SVPWM) signal generation.

\begin{tabular}{cccccccc}
\hline Position & $\mathbf{A}^{\prime}$ & A & $\mathbf{B}^{\prime}$ & $\mathbf{B}$ & $\mathbf{C}^{\prime}$ & $\mathbf{C}$ & Hex Code \\
\hline 1 & 0 & 1 & 1 & 0 & 1 & 0 & XX68 \\
2 & 0 & 1 & 0 & 1 & 1 & 0 & XX58 \\
3 & 1 & 0 & 0 & 1 & 1 & 0 & XX98 \\
4 & 1 & 0 & 0 & 1 & 0 & 1 & XX94 \\
5 & 1 & 0 & 1 & 0 & 0 & 1 & XXa4 \\
6 & 0 & 1 & 1 & 0 & 0 & 1 & XX64 \\
\hline
\end{tabular}

To reduce the computation time of the controller, a lookup table with 864 states is included; thus, we obtained a two-level inverter output. Buffer (74HC244) is used to select the modes. 


\section{Results}

In this section, experimental results with different combinations of the three modes are discussed in detail.

Case-1: In this case, the battery acts as a source and provides power to the resistive load (mode-1). Here, inverter voltage and current for case-1, for SVPWM-based outputs, are obtained from the inverter.

The input voltage obtained from the battery to inverter is $24 \mathrm{~V} \mathrm{DC}$. The output obtained with line to line voltage is 12 volts with a current of $1.2 \mathrm{~A}$ (Figure 33) (readings measured across $1 \mathrm{ohm}$ resistor connected in line with RL load). The waveform below (Figure 34) shows the phase displacement between different phase voltages of the inverter.

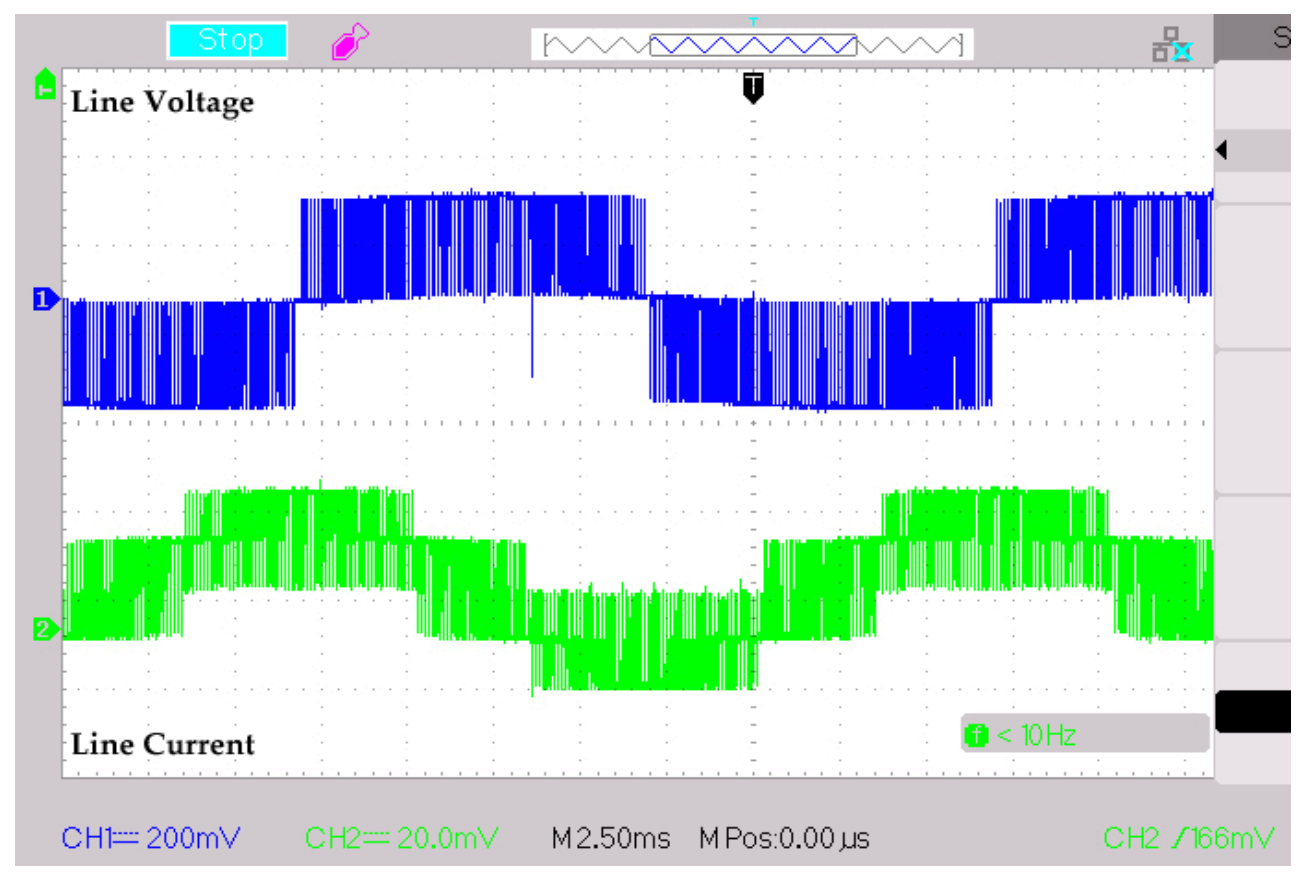

Figure 33. Line voltage and current at inverter output.

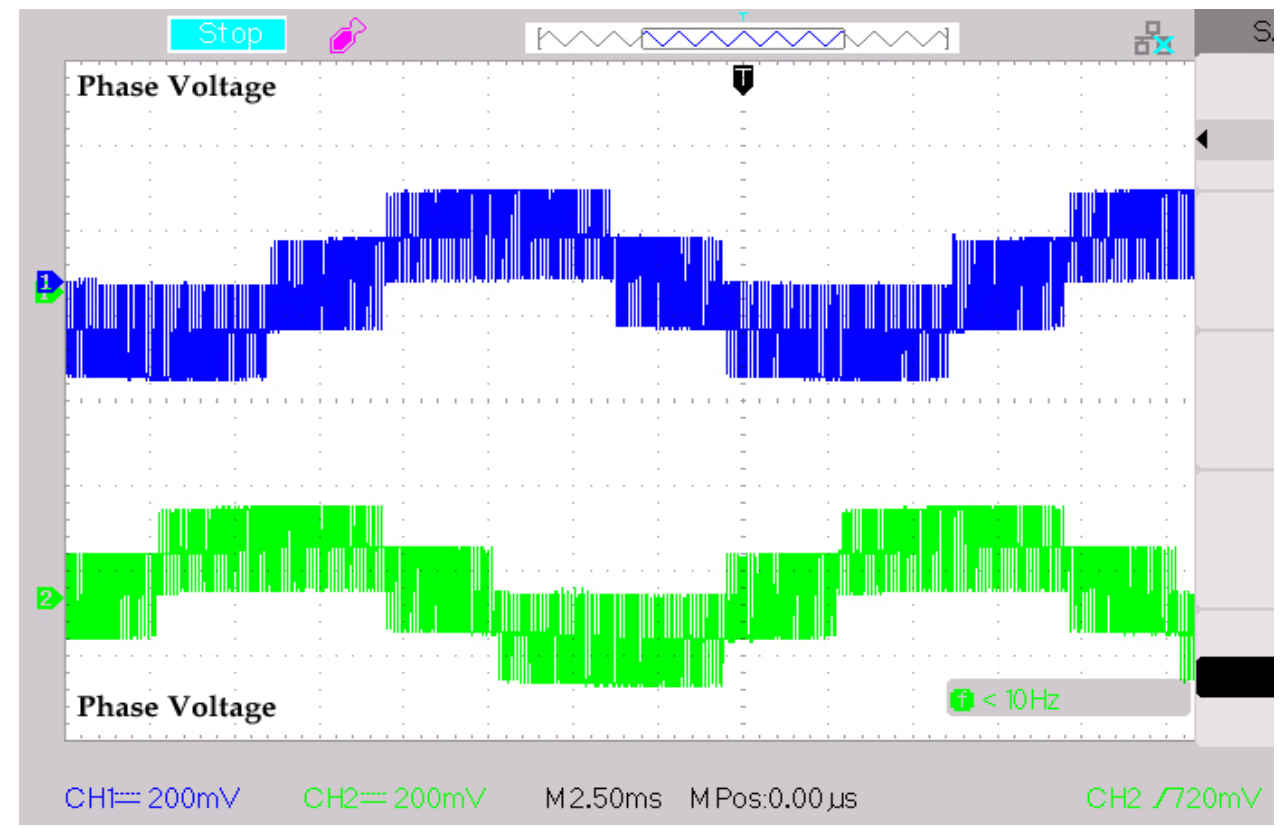

Figure 34. Phase voltages at inverter output. 
The output with input for case-1 (Figure 35), where the battery supplies power to the load, is as follows. Readings of battery current are noted by a variation in the three phase load with continuous intermittent switching of $10 \mathrm{~s}$.

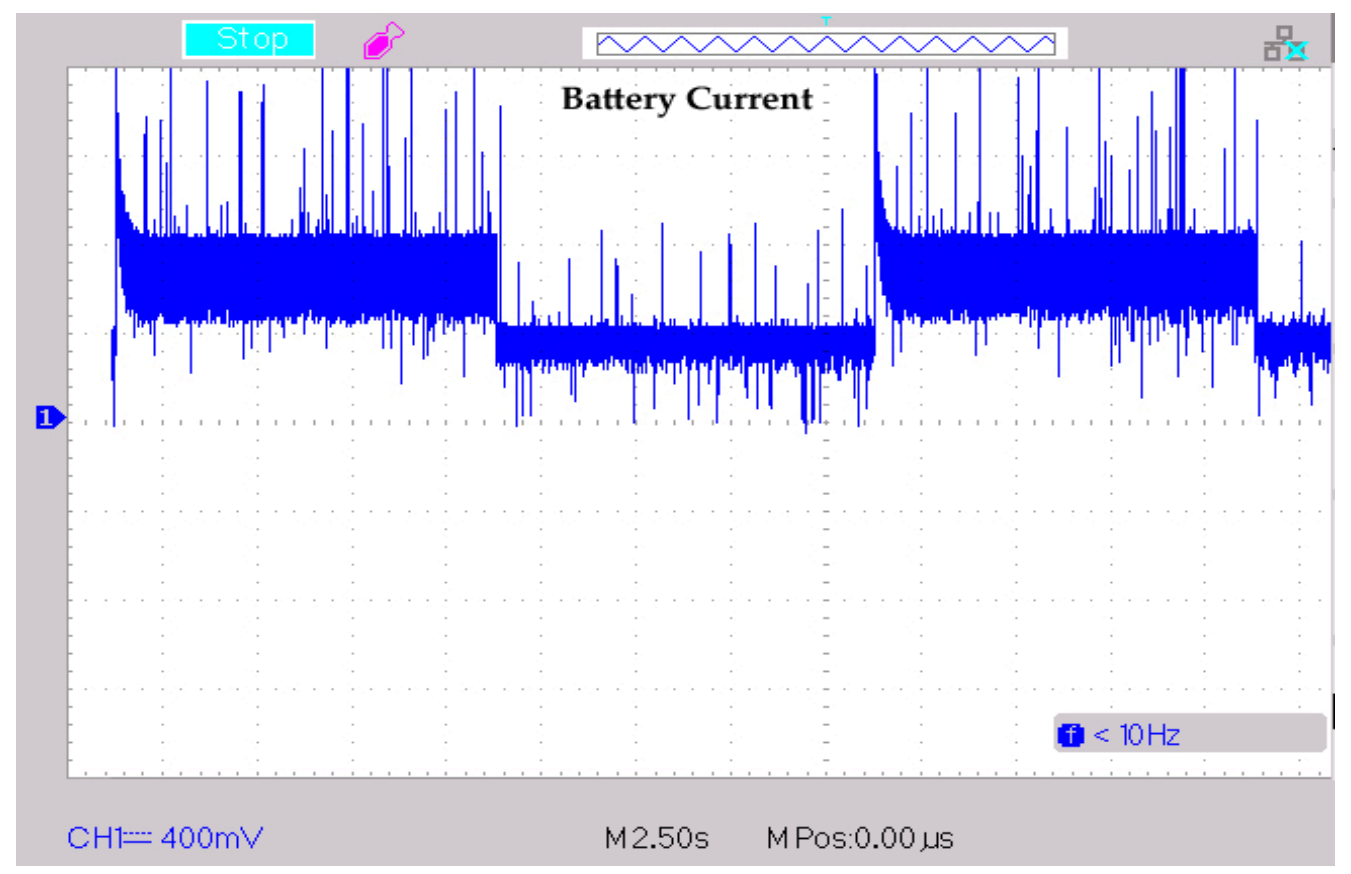

Figure 35. Battery current.

In this case, the total energy requirement is fulfilled by the battery alone. The current drawn from the battery in this case is $4 \mathrm{~A}$ for $5 \mathrm{~s}$ and $2 \mathrm{~A}$ for next $5 \mathrm{~s}$ interval, which gives an average battery current of $3 \mathrm{~A}$.

Case-2: By using latch enable signals, the mode can be changed. This is the proposed mode (Figure 36) where findings and conclusions are analyzed and interpreted by applying a combination of different sources simultaneously (mode-2, mode-3).

By adjusting the duty cycle of source utilization, the prototype is tested for different combinations of sources. The duty cycle adjustment provision is incorporated in the hardware using a potentiometer. The duty cycle is set for three different combinations and the average current of the battery is calculated for a constant load. A battery alone and the battery ultra-capacitor combination are used for $0.5 \mathrm{~ms}$ throughout the cycle. The battery current for mode- 2 is $1.60 \mathrm{~A}$; for mode-3, it is $0.04 \mathrm{~A}$. The average battery current obtained for $1 \mathrm{~ms}$ with the two modes concerned was found to be $0.82 \mathrm{~A}$.

Case-3: In this case (Figure 37) the load is fulfilled through individual ultracapacitor, battery and ultracapacitor together, and individual battery for $0.5 \mathrm{~ms}$ each. For mode- 3 , the battery current is $0.04 \mathrm{~A}$, for mode- 2 it is $1.6 \mathrm{~A}$ and for mode- 1 it is $2.8 \mathrm{~A}$. The average battery current is $1.48 \mathrm{~A}$.

Case-4 This case involves the load being fulfilled through a battery and ultracapacitor together (mode-2), and individual battery (mode-1), for $0.5 \mathrm{~ms}$ each. 


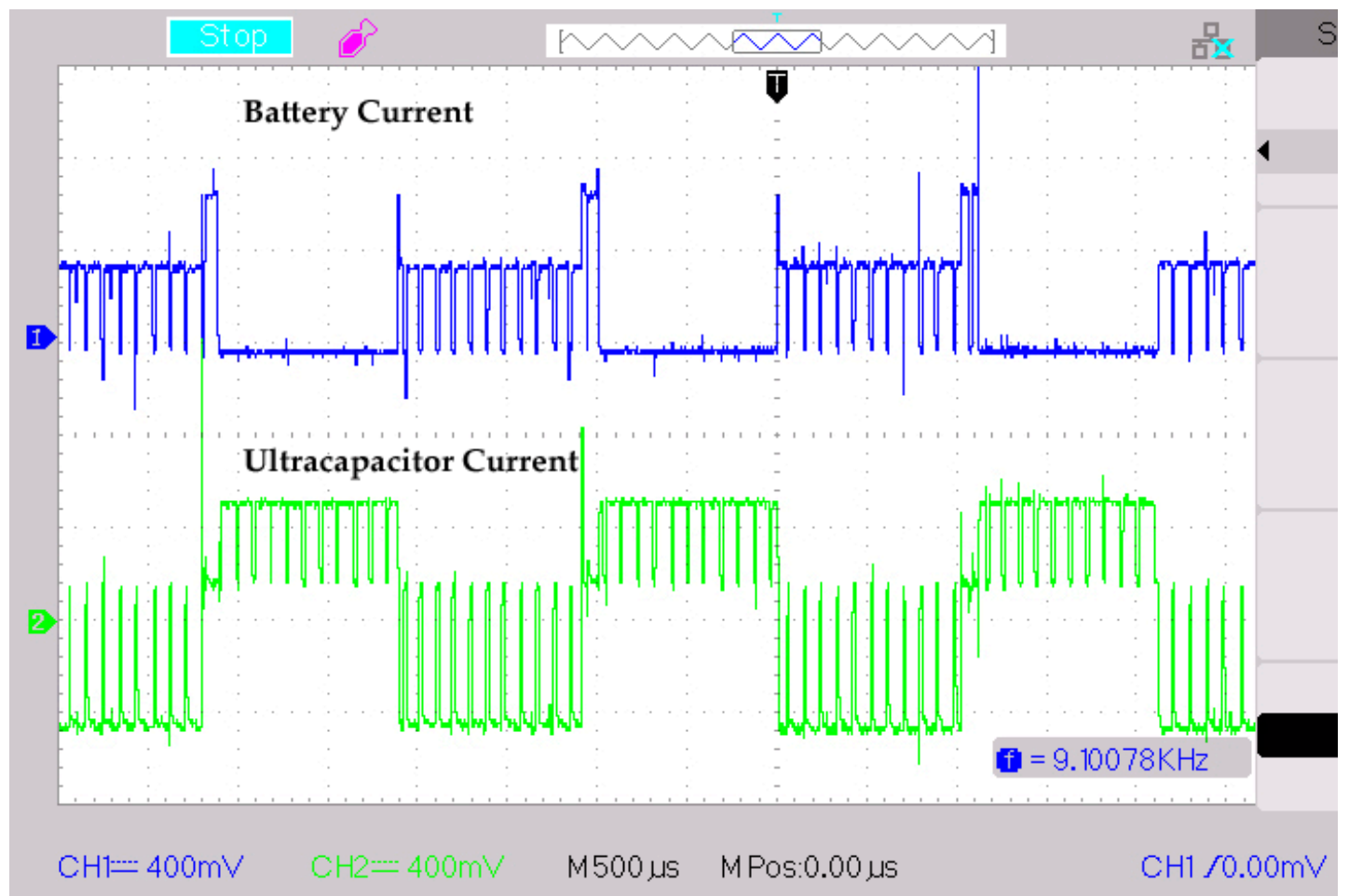

Figure 36. Battery and ultra-capacitor currentsmode- 2 and mode- 3 with $\mathrm{t}_{1}=0.5 \mathrm{~ms} \mathrm{t}_{2}=0.5 \mathrm{~ms}$.

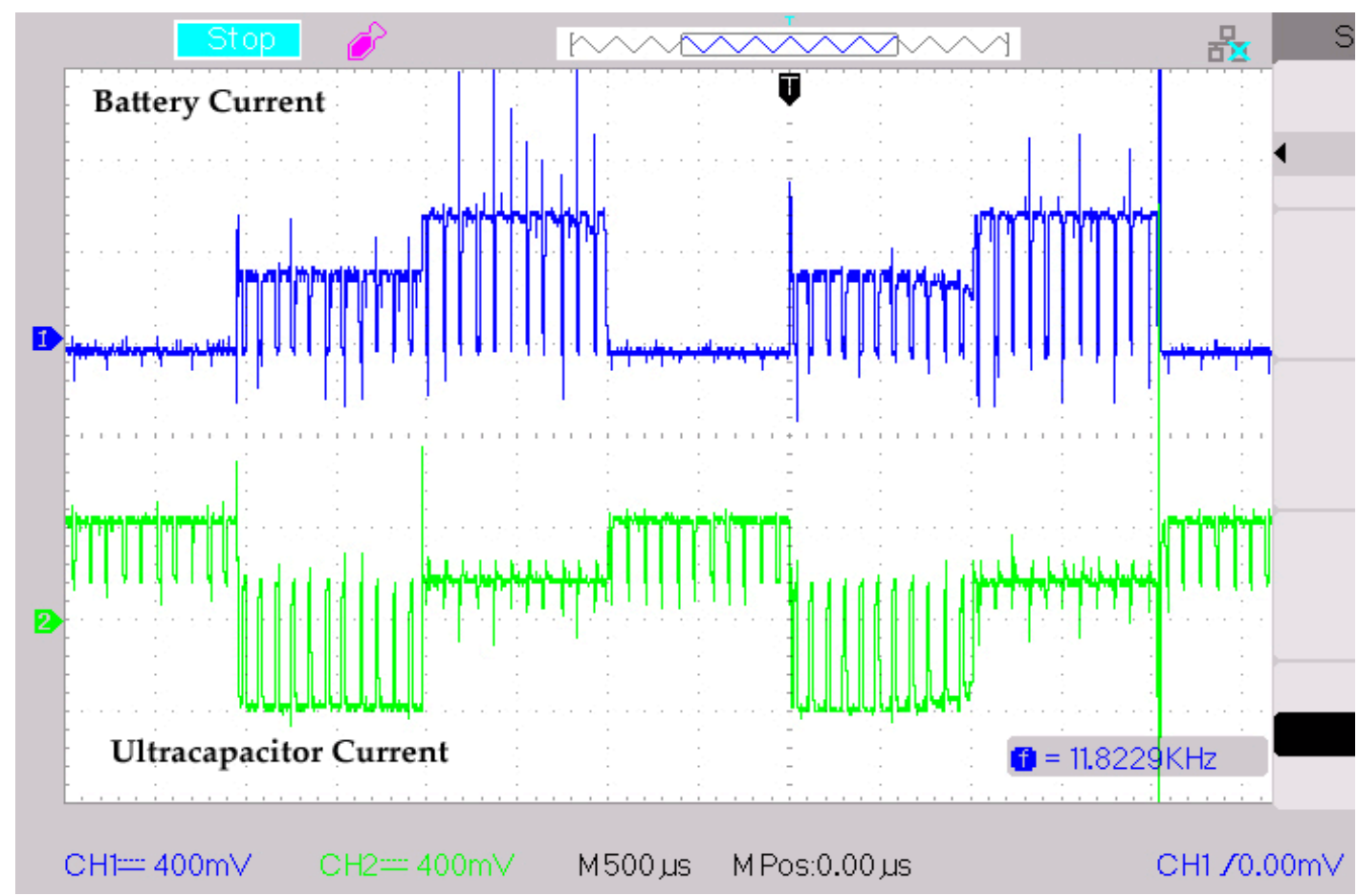

Figure 37. Battery and ultracapacitor currents, mode- 3 , mode- 2 , and mode- 1 with $\mathrm{t}_{1}=0.5 \mathrm{~ms}, \mathrm{t}_{2}=$ $0.5 \mathrm{~ms}, \mathrm{t}_{3}=0.5 \mathrm{~ms}$.

The above waveforms (Figure 38) depict the load shared by the battery alone, i.e., mode-1 (2.4A), and the load shared when the battery and ultra-capacitor, i.e., mode-2, are used together (1.2 A). The average battery current obtained with these modes (mode-2 and mode-3) is $1.8 \mathrm{~A}$. 


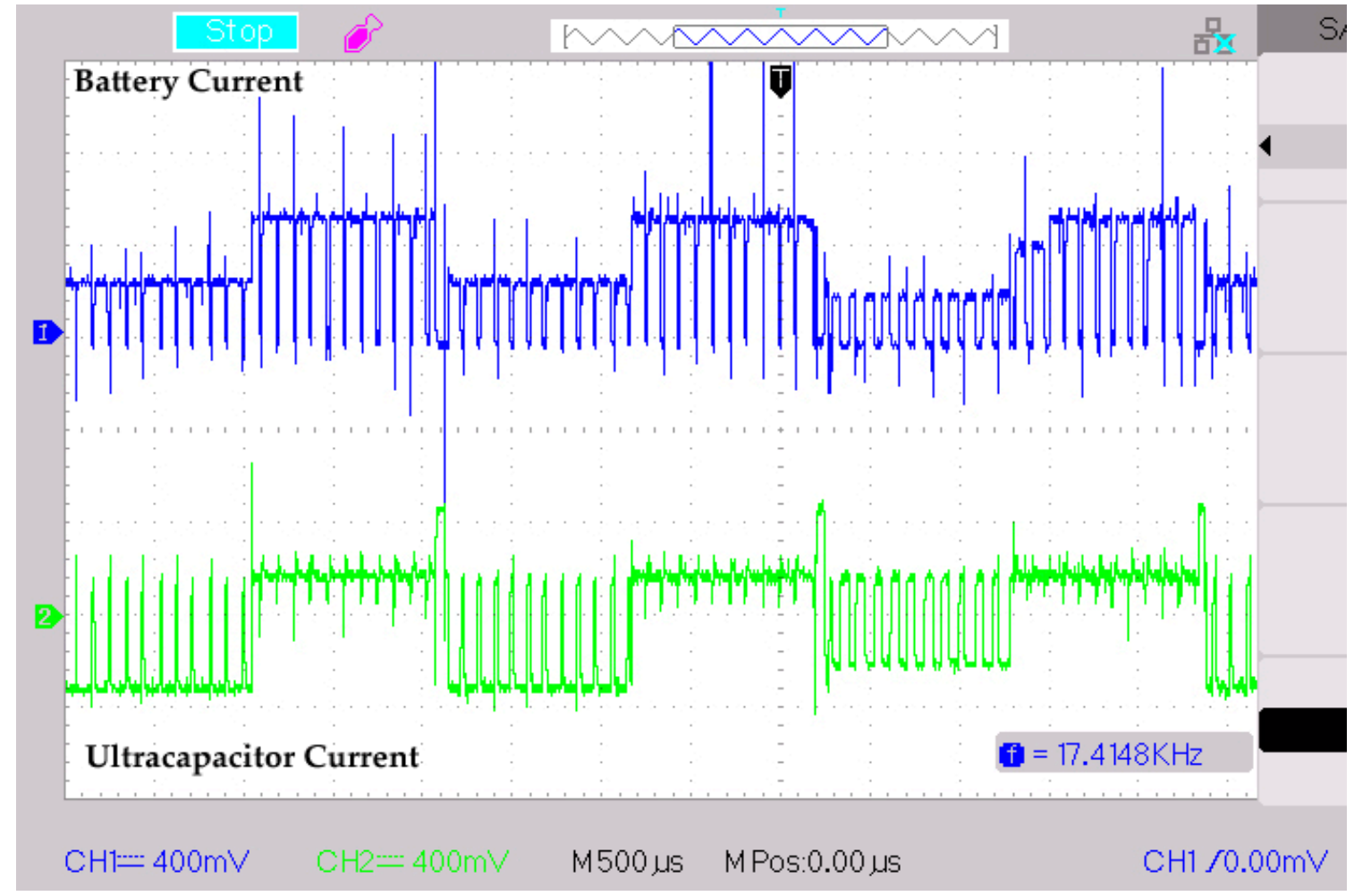

Figure 38. Battery and ultra-capacitor currents, mode- 2 , mode- 1 with $\mathrm{t}_{1}=0.5 \mathrm{~ms}, \mathrm{t}_{2}=0.5 \mathrm{~ms}$.

As an ultracapacitor is used to supply power demands of short duration, mode- 3 cannot be used independently to meet long-term energy requirements.

Here (Table 6), we use the conventional mode (battery supplying energy) or a mixed mode, wherein the ultracapacitor alone and the battery and ultra-capacitor together can be preferred to minimize the average battery current. This enhances the operating cycle/driving cycle of an electric vehicle (or any load). Mixed mode (case-2) gives an average current of $0.82 \mathrm{~A}$ in comparison to the individual battery mode, which gives an average battery current of $3 \mathrm{~A}$, which clearly shows average battery current $27.33 \%(0.82 \mathrm{~A} \times 100 / 3 \mathrm{~A})$ compared to other modes of control (case-1), thereby leading to a much improved range of driving cycles.

Table 6. Current comparison for different cases.

\begin{tabular}{ccccc}
\hline & $\begin{array}{c}\text { Case-1 } \\
\text { (Mode-1) }\end{array}$ & $\begin{array}{c}\text { Case-2 } \\
\text { (Mode-2\&3) }\end{array}$ & $\begin{array}{c}\text { Case-3 } \\
\text { (Mode-1,2 \& 3) }\end{array}$ & $\begin{array}{c}\text { Case-4 } \\
\text { (Mode-1\&2) }\end{array}$ \\
\hline $\begin{array}{c}\text { Average Battery Current } \\
\text { Ultracapacitor Current } \\
\text { (Discharging) }\end{array}$ & $3 \mathrm{~A}$ & $0.82 \mathrm{~A}$ & $1.48 \mathrm{Amp}$ & $1.8 \mathrm{Amp}$ \\
& $0 \mathrm{~A}$ & $2 \mathrm{~A}$ & $2 \mathrm{~A}$ & $1.6 \mathrm{~A}$ \\
\hline
\end{tabular}

The experimental work was carried out using a small prototype of an energy management system consisting of a battery, ultra-capacitors, a control board, a power supply, and a digital storage oscilloscope with a differential probe.

The hardware (Figure 39) was tested for different cases via mode-1, mode-2, and mode-3. 


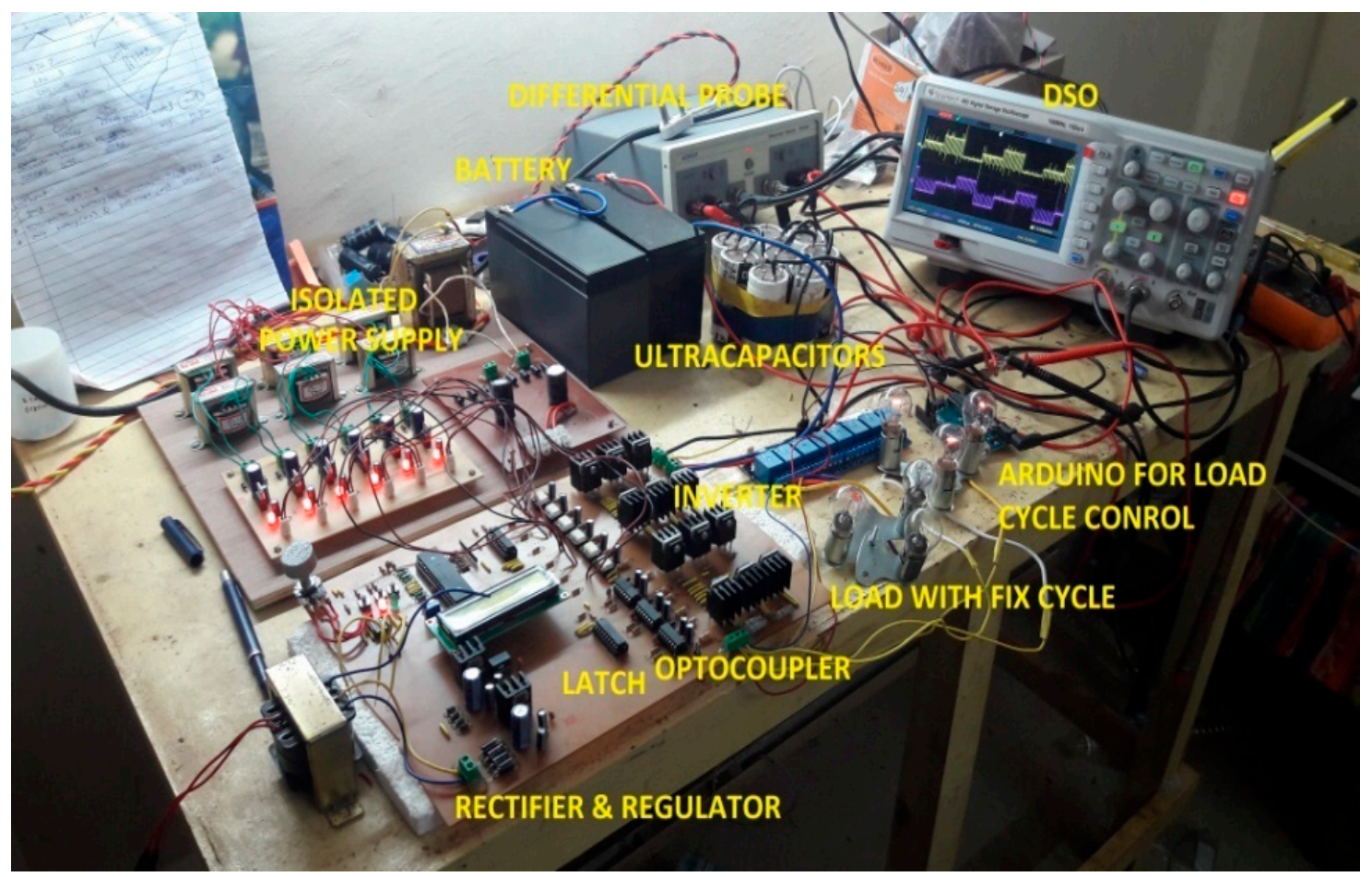

Figure 39. Experimental setup.

\section{Conclusions}

In this paper, a suitable multi-source inverter topology for HESS was proposed. The main advantage of this topology is that it does not add any additional stages between the grid/motor and battery. This novel multisource connection results in improved power demand fulfillment of the load, thereby improving the efficiency of electric vehicles. Also, with a multi-source inverter, smooth current sharing and lower average currents are achieved. On the other hand, the battery can directly drive a motor without any boost operation, as is done with a DC/DC converter, thereby reducing the overall cost of the converter and also increasing the EMS efficiency. Active power and energy sharing between multiple sources is possible during dynamic load demands obtained using a SVPWM-based control strategy, which improves the stability of the load as an induction motor. Finally, the performance of a multisource inverter topology is studied with a scaled-down prototype. From experimentation, it is observed that with multisource topology, a higher driving range is achieved with a reduction in the average current of $27 \%$ compared to that drawn from a battery during conventional modes of EMS control with greater thermal stability, a reduction in overall size, and an enhancement of the life time of an energy storage system.

Author Contributions: Y.M. wrote the original draft; presented the methodology, simulation, and hardware environment with technical data and practical information to make this study applicable for industry; and investigated the results from a technical point of view. K.V. reviewed and edited the manuscript and also provided supervision.

Funding: This research received no external funding.

Acknowledgments: We acknowledge Sutar Amol make for the support to our research group.

Conflicts of Interest: The authors declare no conflict of interest.

\section{References}

1. Pereirinha, P.G.; Trovão, J.P. Multiple Energy Sources Hybridization: The Future of Electric Vehicles? Chapter 8. In New Generation of Electric Vehicles; IntechOpen: London, UK, 2012; pp. 237-262. [CrossRef] 
2. Burke, A.F. Batteries and Ultracapacitors for Electric, Hybrid, and Fuel Cell Vehicles. Proc. IEEE 2007, 95, 806-820. [CrossRef]

3. Sauer, D.U.; Kleimaier, M.; Glaunsinger, W. Relevance of energy storage in future distribution networks with high penetration of renewable energy sources. In Proceedings of the CIRED 2009 20th International Conference and Exhibition on Electricity Distribution, Prague, Czech Republic, 8-11 June 2009; pp. 1-4.

4. Akatsu, K.; Watanabe, N.; Fujitsuna, M.; Doki, S.; Fujimoto, H. Recent Related Technologies for EV/HEV Applications in Japan. In Proceedings of the IEEE ECCE Asia Downunder, Melbourne, Australia, 3-6 June 2013; pp. 141-146.

5. Lukic, S.M.; Cao, J.; Bansal, R.C.; Rodriguez, F.; Emadi, A. Energy Storage Systems for Automotive Applications. IEEE Trans. Ind. Electron. 2008, 55, 2258-2267. [CrossRef]

6. Somayajula, D.; Crow, M.L. An Integrated Active Power Filter-Ultracapacitor Design to Provide Intermittency Smoothing and Reactive Power Support to the Distribution Grid. IEEE Trans. Sustain. Energy 2014, 5, 1116-1125. [CrossRef]

7. Manfredi, S.; Paganm, M.; Raimo, R. Ultracapacitor-based Distributed Energy Resources to support time-varying smart-grid power flows. In Proceedings of the International Symposium on Power Electronics, Electrical Drives, Automation and Motion, Sorrento, Italy, 20-22 June 2012; pp. 1148-1153.

8. Li, X.; Zhang, L.; Wang, Z.; Dong, P. Remaining useful life prediction for lithium-ion batteries based on a hybrid model combining the long short-term memory and Elman neural networks. J. Energy Storage 2019, 21, 510-518. [CrossRef]

9. Zhang, J.; Zhang, L.; Sun, F.; Wang, Z. An Overview on Thermal Safety Issues of Lithium-ion Batteries for Electric Vehicle Application. IEEE Access 2018, 6, 23848-23863. [CrossRef]

10. Li, X.; Wang, Z.; Zhang, L.; Zou, C.; Dorrell, D.D. State-of-health estimation for Li-ion batteries by combing the incremental capacity analysis method with grey relational analysis. J. Power Sources 2019, 410-411, 106-114. [CrossRef]

11. Wang, Z.; Ma, J.; Zhang, L. State-of-health estimation for lithium-ion batteries based on the multi-island genetic algorithm and the gaussian process regression. IEEE Access 2017, 5, 21286-21295. [CrossRef]

12. Zhang, L.; Hu, X.; Wang, Z.; Sun, F.; Deng, J.; Dorrell, D. Multi-objective optimal sizing of hybrid energy storage system for electric vehicles. IEEE Trans. Veh. Technol. 2018, 67, 1027-1035. [CrossRef]

13. Aharon, I.; Kuperman, A. Topological Overview of Powertrains for Battery-Powered Vehicles with Range Extenders. IEEE Trans. Power Electron. 2011, 26, 868-876. [CrossRef]

14. Schupbach, R.M.; Balda, J.C.; Zolot, M.; Kramer, B. Design methodology of a combined battery-ultracapacitor energy storage unit for vehicle power management. In Proceedings of the IEEE 34th Annual Conference on Power Electronics Specialist (PESC 03), Acapulco, Mexico, 15-19 June 2003.

15. Emadi, A.; Rajashekara, K.; Williamson, S.S.; Lukic, S.M. Topological Overview of Hybrid Electric and Fuel Cell Vehicular Power System Architectures and Configurations. IEEE Trans. Veh. Technol. 2005, 54, 763-770. [CrossRef]

16. Cao, J.; Emadi, A. A new battery/ultracapacitor hybrid energy storage system for electric, hybrid, and plug-in hybrid electric vehicles. IEEE Trans. Power Electron. 2012, 27, 122-132.

17. Lukic, S.M.; Wirasingha, S.G.; Rodriguez, F.; Jian, C.; Emadi, A. Power management of an ultracapacitor/ battery hybrid energy storage system in an HEV. In Proceedings of the 2006 IEEE Vehicle Power and Propulsion Conference, Windsor, UK, 6-8 September 2006; pp. 1-6.

18. Dorn-Gomba, L.; Magne, P.; Danen, B.; Emadi, A. On the concept of the multi-source inverter for hybrid electric vehicle powertrains. IEEE Trans. Power Electron. 2018, 33, 7376-7386. [CrossRef]

19. Dorn-Gomba, L.; Emadi, A. A novel Hybrid Energy Storage System Using the Multi Source Invereter. In Proceedings of the 2018 IEEE Applied Power Electronics Conference and Exposition (APEC), San Antonio, TX, USA, 4-8 March 2018.

20. Soltani, M.; Ronsmans, J.; Kakihara, S.; Jaguemont, J.; Van den Bossche, P.; Van Mierlo, J.; Omar, N. Hybrid Battery/Lithium-Ion Capacitor Energy Storage System for a Pure Electric Bus for an Urban Transportation Application. Appl. Sci. 2018, 8, 1176. [CrossRef]

21. Xiangjun, L.; Liangfei, X.; Jianfeng, H.; Jianqiu, L.; Minggao, O. Regenerative braking control strategy for fuel cell hybrid vehicles using fuzzy logic. In Proceedings of the International Conference on Electrical Machines and Systems, Wuhan, China, 17-20 October 2008; pp. 2712-2716. 
22. Wu, X.; Wang, T. Optimization of Battery Capacity Decay for Semi-Active Hybrid Energy Storage System Equipped on Electric City Bus. Energies 2017, 10, 792. [CrossRef]

23. Xiangjun, L.; Liangfei, X.; Jianfeng, H.; Jianqiu, L.; Minggao, O. Control algorithm of fuel cell/battery hybrid vehicular power system. In Proceedings of the IEEE Vehicle Power and Propulsion Conference, Harbin, Hei Longjiang, China, 3-5 September 2008; pp. 1-6.

24. Jiya, I.N.; Gurusinghe, N.; Gouws, R. Combination of LiCs and EDLCs with Batteries: A New Paradigm of Hybrid Energy Storage for Application in EVs. World Electr. Veh. J. 2018, 9, 47. [CrossRef]

25. Miñambres-Marcos, V.M.; Guerrero-Martínez, M.Á.; Barrero-González, F.; Milanés-Montero, M.I. A Grid Connected Photovoltaic Inverter with Battery-Supercapacitor Hybrid Energy Storage. Sensors 2017, 17, 1856. [CrossRef] [PubMed]

26. Liu, J.; Jin, T.; Liu, L.; Chen, Y.; Yuan, K. Multi-Objective Optimization of a Hybrid ESS Based on Optimal Energy Management Strategy for LHDs. Sustainability 2017, 9, 1874. [CrossRef]

27. Jiuyu, D.; Minggao, O.; Wang, H. Battery electric vehicle parameters design targeting to cost-benefit objective. In Proceedings of the IEEE Vehicle Power and Propulsion Conference, Seoul, Korea, 9-12 October 2012; pp. 1160-1164.

28. Trovão, J.P.; Jorge, H.M.; Pereirinha, P.G. Design Methodology of Energy Storage Systems for a Small Electric Vehicle. In Proceedings of the EVS24, Stavanger, Norway, 13-16 May 2009.

29. Trovao, J.P.F.; Santos, V.D.N.; Antunes, C.H.; Pereirinha, P.G.; Jorge, H.M. A real-time energy management architecture for multisource electric vehicles. IEEE Trans. Ind. Electron. 2015, 62, 3223-3233. [CrossRef]

(C) 2019 by the authors. Licensee MDPI, Basel, Switzerland. This article is an open access article distributed under the terms and conditions of the Creative Commons Attribution (CC BY) license (http://creativecommons.org/licenses/by/4.0/). 